Research Paper

\title{
Chlorination and oxidation of human plasma fibronectin by myeloperoxidase-derived oxidants, and its consequences for smooth muscle cell function
}

\author{
Tina Nybo ${ }^{\mathrm{a}}$, Huan Cai ${ }^{\mathrm{a}}$, Christine Y. Chuang ${ }^{\mathrm{a}}$, Luke F. Gamon ${ }^{\mathrm{a}}$, Adelina Rogowska-Wrzesinska ${ }^{\mathrm{b}}$, \\ Michael J. Davies ${ }^{\mathrm{a}, *}$
}

a Department of Biomedical Sciences, Panum Institute, University of Copenhagen, Copenhagen, Denmark

${ }^{\mathrm{b}}$ Department of Biochemistry and Molecular Biology and VILLUM Center for Bioanalytical Sciences, University of Southern Denmark, Odense, Denmark

\section{A R T I C L E I N F O}

\section{Keywords:}

Fibronectin

Myeloperoxidase

Hypochlorous acid

3-chlorotyrosine

Oxidation

Chlorination

Extracellular matrix

Vascular smooth muscle cells

\begin{abstract}
A B S T R A C T
Fibronectin (FN) occurs as both a soluble form, in plasma and at sites of tissue injury, and a cellular form in tissue extracellular matrices (ECM). FN is critical to wound repair, ECM structure and assembly, cell adhesion and proliferation. FN is reported to play a critical role in the development, progression and stability of cardiovascular atherosclerotic lesions, with high FN levels associated with a thick fibrotic cap, stable disease and a low risk of rupture. Evidence has been presented for FN modification by inflammatory oxidants, and particularly myeloperoxidase (MPO)-derived species including hypochlorous acid ( $\mathrm{HOCl}$ ). The targets and consequences of FN modification are poorly understood. Here we show, using a newly-developed MS protocol, that $\mathrm{HOCl}$ and an enzymatic MPO system, generate site-specific dose-dependent Tyr chlorination and dichlorination (up to 16 of 100 residues modified), and oxidation of $\operatorname{Trp}$ (7 of 39 residues), Met ( 3 of 26) and His (1 of 55) within selected FN domains, and particularly the heparin- and cell-binding regions. These alterations increase FN binding to heparin-containing columns. Studies using primary human coronary artery smooth muscle cells (HCASMC) show that exposure to $\mathrm{HOCl}$-modified $\mathrm{FN}$, results in decreased adherence, increased proliferation and altered expression of genes involved in ECM synthesis and remodelling. These findings indicate that the presence of modified fibronectin may play a major role in the formation, development and stabilisation of fibrous caps in atherosclerotic lesions and may play a key role in the switching of quiescent contractile smooth muscle cells to a migratory, synthetic and proliferative phenotype.
\end{abstract}

\section{Introduction}

Fibronectin (FN) is a large plasma and extracellular matrix glycoprotein, composed of two nearly identical subunits $(\sim 230-270 \mathrm{kDa})$ linked by two disulfide-bonds located near the carboxyl termini $[1,2]$. The protein exists in two forms: a soluble form predominantly found in plasma, but also in abundance at sites of tissue injury, and a cellular form present in tissue extracellular matrix (ECM). The plasma form plays a key role in the early physiological responses to tissue injury as it binds to fibrin fibres via multiple domains and hence is a key component of blood clots [3]. The resulting fibrin-FN network supports migration and adhesion of fibroblast and endothelial cells which over time replace this provisional matrix structure with cell-derived FN, collagen, laminins and other ECM components [4,5]. Cell-derived FN, which is synthesized by endothelial, smooth muscle and fibroblast cells, amongst others, is structurally-related to the plasma form, but also contains extra domains (extra domains A and B) which are alternatively spliced type III modules that are not present in the plasma form [6].

$\mathrm{FN}$ is present in the ECM of the arterial wall under normal physiological conditions [7], but a significant increase in concentration, and different isoforms, have been reported in atherosclerotic lesions [8]; these changes appear to occur during lesion development [9]. Patients with coronary artery disease also have elevated levels of plasma FN [10]. These changes may be associated with remodelling of the vascular

\footnotetext{
Abbreviations: 3-ClTyr, 3-chlorotyrosine; 3,5- $\mathrm{Cl}_{2}$ Tyr, 3,5-dichlorotyrosine; ECM, extracellular matrix; ELISA, enzyme-linked immunosorbent assay; FN, human

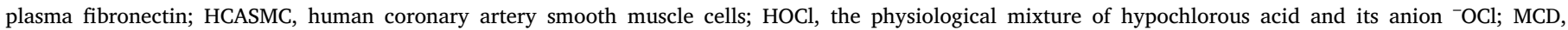

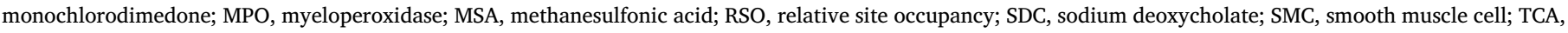
trichloroacetic acid; TFA, trifluoroacetic acid; TMB, 3,3',5,5'-tetramethylbenzidine

* Corresponding author.

E-mail address: davies@sund.ku.dk (M.J. Davies).
} 
wall during the development of atherosclerosis, with considerable evidence for increased ECM deposition in the fibrous caps of atherosclerotic plaques [11]. The formation of a thick fibrous cap is widely regarded as being beneficial with regard to plaque stability [11]. Rupture of the lesion, exposure of the highly thrombogenic substrata, and subsequent thrombus formation, is a major cause of heart attacks and strokes [11]. Rupture prone plaques typically have a thin fibrous cap, increased numbers of activated inflammatory cells capable of producing oxidants, high levels of lipids, and low numbers of smooth muscle cells $[12,13]$. Rupture occurs most commonly in the shoulder regions where macrophages and other leukocytes accumulate [14,15]. Studies on atherosclerosis-prone apo $\mathrm{E}^{-/-}$mice that do not express plasma-derived FN, have shown a reduction in number and size of atherosclerotic lesions, however mice deficient in plasma-derived FN lacked vascular smooth muscle cell infiltration and failed to develop a fibrous cap [16]. These data are consistent with the hypothesis that FN plays a critical role in generating and stabilizing the fibrous cap of atherosclerotic lesions, and plays a major role in determining lesion stability and propensity to rupture. The colocalization of inflammatory cells with FN in plaque shoulder regions, and FN degradation during the progression of atherosclerosis, supports the hypothesis that plaques are damaged and destabilized by inflammatory cell oxidants, with this occurring, at least in part, via ECM damage $[17,18]$.

Oxidants are intentionally generated during many physiologic and pathological processes [19]. Activated leukocytes generate superoxide radicals $\left(\mathrm{O}_{2}{ }^{-}\right)$and hydrogen peroxide $\left(\mathrm{H}_{2} \mathrm{O}_{2}\right)$ via NADPH oxidase (NOX) enzymes, and neutrophils, monocytes and some tissue macrophages release the heme enzyme myeloperoxidase (MPO) from intracellular storage granules [20]. In the presence of chloride ions $\left(\mathrm{Cl}^{-}\right)$, MPO utilizes $\mathrm{H}_{2} \mathrm{O}_{2}$ to generate the potent oxidant hypochlorous acid ( $\mathrm{HOCl})[20,21]$. $\mathrm{HOCl}$ reacts rapidly with many biological targets, with kinetic data indicating that proteins are major targets, due to their abundance and high reactivity $[21,22]$. Although $\mathrm{HOCl}$ plays an important role in killing invading pathogens, excessive or misplaced generation can result in host tissue damage, with this being associated with multiple human pathologies involving acute or chronic inflammation, including atherosclerosis [21,23-25].

There is limited data on $\mathrm{HOCl}$-induced modifications to isolated FN, or FN in the arterial wall, though it is known that FN can be modified by $\mathrm{HOCl}$ both in vitro, and in basement membrane preparations from other tissues [26-28]. Modified FN colocalizes with leukocyte-derived MPO in human atherosclerotic lesions [29], but the nature of the modifications induced on FN by MPO-derived oxidants are unknown. Sulfurcontaining amino acids (Cys, Met and cystine) are major targets for HOCl $[22,30,31]$, however FN has low levels of Cys, though a large number of Met and disulfide (cystine) bonds; these are therefore likely to be major targets, if they are accessible. $\mathrm{HOCl}$ can also modify His, Trp, Lys and Tyr residues [22] though the chloramines (RNHCl species) formed on His and Lys have limited stability and hence cannot be easily quantified in vivo [32,33]. Reaction of $\mathrm{HOCl}$ and chloramines with Tyr generates the well-established biomarker 3-chlorotyrosine (3Cl-Tyr) [34-36]. This stable product is characteristic of MPO-mediated damage, as it is the only enzyme known to induce significant levels of chlorination [35]. Elevated 3Cl-Tyr levels have been detected on lowand high-density lipoproteins extracted from atherosclerotic lesions, and also on plasma proteins from people with cardiovascular disease [36-40].

The studies reported here aimed to determine whether human plasma FN is susceptible to damage induced by HOCl and a MPO-catalysed system, to identify the nature and sites of damage using a recently developed proteomics approach [41], and to examine whether oxidant-modified FN has functional effects on human coronary artery smooth muscle cells, a key cell type within the artery wall.

\section{Materials and methods}

\subsection{Materials}

All chemicals were purchased from Sigma Aldrich except for: human plasma fibronectin (FN) (Corning or Sigma-Aldrich), human myeloperoxidase (Planta Natural Products), lysyl endopeptidase (Lys-C) (Wako), and 3-chloro- $\left[{ }^{13} \mathrm{C}_{6}\right]$ tyrosine (Cambridge Isotope Laboratories). All solvents were HPLC or LCMS grade. RNA was extracted from cell cultures using an RNeasy kit (Qiagen, Valencia, CA) according to the manufacturers protocol, with cDNA synthesis and quantitative realtime PCR carried out using SuperScript ${ }^{\mathrm{TM}}$ III First-Strand Synthesis SuperMix (Invitrogen) and SYBR ${ }^{\circledR}$ GreenER $^{\mathrm{TM}}$ qPCR SuperMix Universal (Invitrogen), respectively. Human interleukin-6 (IL-6) was determined using an ELISA kit (Biolegend; San Diego, USA) as described by the manufacturer. Human coronary artery smooth muscle cells (donor 1596), SMC growth medium and SMC basal medium were from Cell Applications (San Diego, USA).

\subsection{Quantification of HOCl formation using 3,3',5,5'-tetramethylbenzidine (TMB) or monochlorodimedone (MCD)}

TMB was used to quantify $\mathrm{HOCl}$ production by the $\mathrm{MPO}-\mathrm{H}_{2} \mathrm{O}_{2}-\mathrm{Cl}^{-}$ system as outlined previously [42]. The developing reagent consisted of $20 \mathrm{mM}$ TMB in dimethylformamide, and $2 \mathrm{mM} \mathrm{NaI}$ in sodium acetate buffer $(0.44 \mathrm{M}, \mathrm{pH} 5.4)$ prepared immediately prior to use. The MPO$\mathrm{H}_{2} \mathrm{O}_{2}-\mathrm{Cl}^{-}\left(20 \mathrm{nM}\right.$ MPO, $0-200 \mu \mathrm{M} \mathrm{H}_{2} \mathrm{O}_{2}, 200 \mathrm{mM} \mathrm{Cl}^{-}$) or reagent $\mathrm{HOCl}$ $(0-200 \mu \mathrm{M})$ was incubated with taurine $(10 \mathrm{mM})$ at $37^{\circ} \mathrm{C}$ for $2 \mathrm{~h}$. Then, $50 \mu \mathrm{L}$ of TMB reagent was added to each well and incubated for $5 \mathrm{~min}$ at $21^{\circ} \mathrm{C}$. The absorbance at $645 \mathrm{~nm}$ was then measured on a Spectra Max $^{\circledR}$ i3x microplate reader. The concentration of $\mathrm{HOCl}$ formed and trapped by taurine, was calculated using a standard curve generated using reagent HOCl $(0-200 \mu \mathrm{M})$. HOCl production was also quantified by determining the loss of parent MCD spectrophotometrically, using a molar extinction coefficient $\varepsilon_{290} 17,700 \mathrm{M}^{-1} \mathrm{~cm}^{-1}$ [43].

\subsection{Oxidation of human plasma fibronectin (FN)}

Purified FN was prepared in $100 \mathrm{mM}$ sodium phosphate buffer, $\mathrm{pH}$ 7.4 , at a concentration of $1 \mathrm{mg} \mathrm{mL}^{-1}(2.27 \mu \mathrm{M})$. $\mathrm{HOCl}$ was added at 0 , 100 or $500 \mu \mathrm{M}$ and incubated for $1 \mathrm{~h}$ at $21^{\circ} \mathrm{C}$. HOCl stocks were quantified spectrophotometrically at $292 \mathrm{~nm}$ using a molar extinction coefficient $\left(\varepsilon_{292}\right)$ of $350 \mathrm{M}^{-1} \mathrm{~cm}^{-1}$. For MPO-mediated oxidation, aliquots of FN were incubated (unless otherwise indicated) with $0.1 \mu \mathrm{M}$ MPO, $100 \mathrm{mM} \mathrm{NaCl}$ and $500 \mu \mathrm{M} \mathrm{H}_{2} \mathrm{O}_{2}$, with the $\mathrm{H}_{2} \mathrm{O}_{2}$ added as $10 \times 50 \mu \mathrm{M}$ aliquots at $10 \mathrm{~min}$ intervals at $37^{\circ} \mathrm{C}$ on a thermo-shaker, and incubated for a further $10 \mathrm{~min}$ after the final addition. Controls with no MPO, no $\mathrm{H}_{2} \mathrm{O}_{2}$, no $\mathrm{NaCl}$, and untreated $\mathrm{FN}$ were included.

\subsection{Protein digestion for mass spectrometry}

Modified and non-modified proteins were digested in-solution using an optimised protocol without the use of reduction and alkylation, as these reduce the yield of chlorinated products (T. Nybo, M.J. Davies, A. Rogowska-Wrzesinska, unpublished data). Briefly, residual reactants and salts were removed using $10 \mathrm{kDa}$ spin-filters (Amicon Ultra-0.5 Ultracel-10K, Merck Millipore, Ireland), with buffer exchange into $50 \mathrm{mM}$ triethyl ammonium bicarbonate buffer supplemented with $4 \mathrm{M}$ urea and $1 \%$ sodium deoxycholate (SDC) to induce denaturation. Proteins were incubated for $>3 \mathrm{~h}$, followed by a two-step digestion using Lys-C for $2 \mathrm{~h}$ in $4 \mathrm{M}$ urea, followed by trypsin for $18 \mathrm{~h}$ in $1 \mathrm{M}$ urea. The temperature was kept at $30^{\circ} \mathrm{C}$ to minimize protein carbamylation. SDC was removed using acidification and ethyl acetate phase transfer as described previously [44]. 


\subsection{Mass spectrometry analysis of treated samples}

One $\mu \mathrm{g}$ of peptide mixture was separated using a precolumn $(5 \mu \mathrm{m}$ particle size, C18 fused silica beads, $4 \mathrm{~cm} \times 100 \mu \mathrm{m}$ ID) coupled to an analytical column ( $3 \mu \mathrm{m}$ particle size, C18 fused silica beads, $20 \mathrm{~cm} \times$ $75 \mu \mathrm{m}$ ID) mounted on an EASY nLC 1000 instrument (Thermo Fisher Scientific, Germany). Peptides were separated at a flow rate of $250 \mathrm{~nL}$ $\min ^{-1}$ using buffer A $(0.1 \%$ formic acid) with $5-38 \%$ buffer B $(0.1 \%$ formic acid, $90 \%$ acetonitrile), over a 60 min linear gradient, followed by an $8 \mathrm{~min}$ wash, using increasing concentrations of buffer B (38-100\%), and $5 \mathrm{~min}$ of $100 \%$ buffer B. Eluting peptides were analysed on a QExactive HF (Thermo Fisher Scientific) mass spectrometer in positive ion mode using data-dependent acquisition. Full scans of $m$ / z 400-1400 was recorded with 120,000 resolution, with the top 12 most intense ions selected for higher energy collisional dissociation (HCD) fragmentation at a normalised collision energy of 28. Blanks were run between each sample to monitor and prevent carry-over.

\subsection{Relative quantification of oxidative modifications by mass spectrometry}

Mass spectrometry results (.raw, Xcalibur data files) were imported and analysed using Progenesis QI for proteomics (Nonlinear Dynamics, USA). Database searches were carried out using Proteome Discoverer 2.1 against a FN isoform database. For MPO-mediated oxidations, MPO isoform sequences were included in the database. The following search parameters were used: parent ion tolerance - $4 \mathrm{ppm}$; fragment ion tolerance - $0.1 \mathrm{Da}$; trypsin - 2 missed cleavages allowed; fixed modifications - none; variable modifications: $\mathrm{Cl}(\mathrm{Y}, \mathrm{W}), 2 \times \mathrm{Cl}(\mathrm{Y}, \mathrm{W}), 1 \times \mathrm{O}(\mathrm{M}$, $\mathrm{H}, \mathrm{C}, \mathrm{W}), 2 \times \mathrm{O}(\mathrm{M}, \mathrm{C}, \mathrm{W}), 3 \times \mathrm{O}(\mathrm{C})$. The results were exported as pepXML files and imported back into Progenesis. Peptide measurements were exported from Progenesis providing normalised abundance calculated from the extracted ion chromatograms of precursor ions [45]. All identifications were validated by manual inspection of fragment ion spectra and chromatograms. For chlorinated peptides, the isotopic distribution was inspected relative to the native peptide to confirm the characteristic enhancement of the 3rd isotopic isomer arising from the presence of chlorine isotopes [46]. Quantitative values from different charge states were pooled manually. Zero-values from Progenesis were handled in two ways: a) if missing in all replicates, the abundance was assumed to be below the detection limit and for calculation purposes their value was set to 1 ; b) if missing in 1 replicate but present in the remaining, it was assumed to be randomly missing and removed. The relative site occupancy for modification of a particular amino acid was calculated by dividing the sum of signal intensities (area-under-thecurve) of all peptide spectral matches containing the modified position, with the sum of the intensity of all peptide spectral matches containing the position (non-modified and modified) with the values expressed as a percentage.

\subsection{Quantification of total 3-chlorotyrosine levels}

Protein samples $(25 \mu \mathrm{g})$ were precipitated with trichloroacetic acid (TCA; w/v 8\%) and spiked with 3-chloro- $\left[{ }^{13} \mathrm{C}_{6}\right]$ tyrosine $(100 \mathrm{pmol}$, internal standard) before evaporation using a centrifugal vacuum concentrator for $1 \mathrm{~h}$, as described previously [47]. MS experiments using spin filters versus TCA/acetone precipitation for protein purification showed that the use of TCA did not induce artefactual chlorination (T. Nybo, M.J. Davies, A. Rogowska-Wrzesinska, unpublished data). The resulting pellet was hydrolysed overnight in $4 \mathrm{M}$ methanesulfonic acid (MSA, $50 \mu \mathrm{L}$ ) under vacuum at $110^{\circ} \mathrm{C}$. Amino acids were partially purified by solid-phase extraction using $1 \mathrm{~mL} \mathrm{C-18}$ cartridges (Supelco). The columns were activated using $100 \%$ methanol $(1 \mathrm{~mL})$, followed by equilibration with $0.1 \%$ trifluoroacetic acid (TFA) in water $(2 \times 1 \mathrm{~mL})$. Samples were diluted with $1 \%$ TFA in water $(10 \mu \mathrm{L}$ hydrolysate in $400 \mu \mathrm{L}$ of $1 \% \mathrm{TFA}$ ) in order to improve ion-pairing and subsequent binding of amino acids to the C18 material. The samples were loaded onto the column and washed with $0.1 \%$ TFA in water $(1 \times 1 \mathrm{~mL})$ followed by elution with $50 \%$ methanol containing $0.1 \%$ formic acid $(1 \times 1 \mathrm{~mL})$. Extracts were dried at $60^{\circ} \mathrm{C}$ under vacuum for $4 \mathrm{~h}$ and dissolved in $50 \mu \mathrm{L}$ of $0.1 \%$ formic acid.

3-Chlorotyrosine (3-ClTyr) was quantified by electrospray ionisation LC-MS in the positive ion mode using a Bruker Impact HD II mass spectrometer. Samples were separated by gradient elution using a Phenomenex Aeris $^{\mathrm{TM}} 2.6 \mu \mathrm{m}$ PEPTIDE XB-C18 $250 \times 2.1 \mathrm{~mm}$ HPLC column. Elution was started at 3\% B for $1 \mathrm{~min}$, followed by gradient elution from $3 \%$ to $50 \%$ B over 9 mins, $50-80 \%$ B over 2 min, followed by isocratic elution using $80 \% \mathrm{~B}$ for 3 mins, before decreasing to $3 \% \mathrm{~B}$ over 2 mins and re-equilibration at $3 \%$ B for 3 min. Buffer A consisted of $0.1 \%$ formic acid in $\mathrm{H}_{2} \mathrm{O}$ and buffer B consisted of $90 \%$ acetonitrile in $\mathrm{H}_{2} \mathrm{O}$. The electrospray needle was held at $4500 \mathrm{~V}$, with end plate offset of $500 \mathrm{~V}$ and temperature of $200{ }^{\circ} \mathrm{C}$. Nitrogen gas was used for both the nebuliser $(2.0 \mathrm{bar})$ and as the dry gas $\left(8.0 \mathrm{~L} \mathrm{~min}^{-1}\right)$. An external standard curve was generated for 3-ClTyr with a concentration range of $78 \mathrm{fmol}$ to 20 pmol loaded onto the column, with the internal standard maintained at 4 pmol. A linear response of 3-ClTyr relative to the internal standard was observed over this concentration range. Standards were prepared in $0.1 \%$ formic acid in $\mathrm{H}_{2} \mathrm{O}$. Spectra were collected in MS1 mode and quantification performed on extracted ion chromatograms for 3-ClTyr $(m / z=216.04)$ and $\left.3-\mathrm{Cl}^{13}{ }^{13} \mathrm{C}_{6}\right] \mathrm{Tyr}(m / z=222.06)$.

\subsection{Heparin-affinity chromatography}

FN $(100 \mu \mathrm{g})$ was loaded onto a HiTrap Heparin High Performance column (GE Healthcare, UK) on a Äkta FPLC system (GE Healthcare, UK) using $10 \mathrm{mM}$ sodium phosphate buffer $\mathrm{pH} 7.4$ at a flow rate of $1 \mathrm{~mL} \mathrm{~min}^{-1}$. Elution was carried out using a $10 \mathrm{~min}$ gradient from $0 \%$ to $100 \%$ of $100 \mathrm{mM} \mathrm{NaCl}$ in $10 \mathrm{mM}$ sodium phosphate buffer, pH 7.4. Protein elution was monitored by UV detection.

\subsection{Cell culture}

Primary human coronary artery smooth muscle cells (HCASMC) were cultured in vitro using commercial smooth muscle cell (SMC) growth medium in a humidified incubator containing $5 \% \mathrm{CO}_{2}$ at $37^{\circ} \mathrm{C}$. HCASMC were cultured for 1 week with an initial density of $10^{4}$ cells in $200 \mu \mathrm{L}$ of medium in 96 -well plate, or at $2 \times 10^{4}$ cells in $500 \mu \mathrm{L}$ of medium in 8-well tissue culture slides, or $10^{6}$ cells in $25 \mathrm{~mL}$ medium in T175 flasks. The growth medium was replaced three times per week.

\subsection{Adhesion of human coronary artery smooth muscle cells (HCASMC) to native and modified FN}

Adhesion of HCASMC to native or modified FN was assessed using black 96-well tissue culture plates pre-coated overnight with purified FN $\left(20 \mu \mathrm{g} \mathrm{mL}^{-1}, \sim 44 \mu \mathrm{M}\right)$. The plate was then treated with $50 \mu \mathrm{L}$ of $\mathrm{HOCl}(1-200 \mu \mathrm{M})$ or a MPO- $\mathrm{H}_{2} \mathrm{O}_{2}-\mathrm{Cl}^{-}$system $(20 \mathrm{nM} \mathrm{MPO}, 1-200 \mu \mathrm{M}$ $\mathrm{H}_{2} \mathrm{O}_{2}, 200 \mathrm{mM} \mathrm{Cl}^{-}$) for $2 \mathrm{~h}$ at $37^{\circ} \mathrm{C}$. The plate was then rinsed twice with sterile PBS to remove any excess oxidant or the enzyme system, before blocking with sterile and heat-denatured $1 \%$ BSA in PBS (w/v) at $37^{\circ} \mathrm{C}$ for $1 \mathrm{~h}$ to minimize non-specific binding of cells to the plastic. The HCASMC $\left(5 \times 10^{6}\right.$ cells $\left.\mathrm{mL}^{-1}\right)$ were pre-loaded before use with $5 \mu \mathrm{M}$ calcein AM for $30 \mathrm{~min}$ at $37^{\circ} \mathrm{C}$, with the cells subsequently washed with pre-warmed basal medium to remove residual dye. The calcein AMlabelled HCASMC were then added at a concentration of $10^{4}$ cells per well to the plates containing native or modified FN, and incubated in a tissue culture incubator for $90 \mathrm{~min}$. The plates were then rinsed twice with PBS (containing $\mathrm{Ca}^{2+}$ and $\mathrm{Mg}^{2+}$ ) to remove non-adherent cells. Fluorescence from the adherent cells was then quantified using a SpectraMax ${ }^{\circledR}$ i $3 x$ microplate reader, with $\lambda_{\text {ex }} 490 \mathrm{~nm}$ and $\lambda_{\text {em }} 520 \mathrm{~nm}$, respectively. Alternatively, adhesion of HCASMC to modified FN was carried out on 8-well glass slides. These were coated with FN, treated with $\mathrm{HOCl}(20$ or $100 \mu \mathrm{M})$, washed, and incubated with HCASMC 
$\left(2 \times 10^{4}\right.$ cells per well $)$ as described above. Adherent cells were rinsed twice with PBS and then fixed with $4 \%$ formaldehyde in PBS $\left(37^{\circ} \mathrm{C}\right.$, $15 \mathrm{~min}$ ) then permeabilized using $0.5 \%(\mathrm{v} / \mathrm{v})$ Triton X-100 in PBS on ice for $5 \mathrm{~min}$. The slides were rinsed again with PBS and counterstained with ActinRed 555 (Life Technologies) and $1 \mu \mathrm{g} \mathrm{mL}{ }^{-1}$ DAPI in PBS in the dark at $21{ }^{\circ} \mathrm{C}$ for $30 \mathrm{~min}$ to stain $\mathrm{F}$-actin and nuclei, respectively. The cells were then rinsed three times with PBS, air dried, had cover slips added, and examined under a fluorescence microscopy (Olympus, Japan). Alternatively the permeabilized HCASMC (as above) were stained with $0.4 \%$ trypan blue for $15 \mathrm{~min}$ at $21^{\circ} \mathrm{C}$, to examine cell morphology using bright field microscopy.

\subsection{Proliferation of HCASMC on native and modified FN}

Black 96-well tissue culture plates coated with native or modified FN were prepared as described above, except the FN was treated with $1 \mu \mathrm{M} \mathrm{HOCl}$ at $37^{\circ} \mathrm{C}$ for $2 \mathrm{~h}$. The plates were then rinsed $(2 \times \mathrm{PBS})$ to remove residual $\mathrm{HOCl}$, and then blocked with sterile and heat-denatured $1 \%(\mathrm{w} / \mathrm{v}) \mathrm{BSA}$ in $\mathrm{PBS}\left(\mathrm{Ca}^{2+}\right.$ and $\mathrm{Mg}^{2+}$-free) at $37^{\circ} \mathrm{C}$ for $1 \mathrm{~h}$ to minimize non-specific binding. HCASMC were pre-loaded with $5 \mu \mathrm{M}$ calcein AM (as above), and then added $\left(10^{4}\right.$ cells per well) to the native or treated FN and incubated for $90 \mathrm{~min}$. The plates were then rinsed (as above) to remove non-adherent cells. The initial (day 0) density of adherent cells was quantified by fluorescence as described above. The plates were then washed twice with PBS (with $\mathrm{Ca}^{2+}$ and $\mathrm{Mg}^{2+}$ ) and replaced with $200 \mu \mathrm{L}$ of growth medium, then incubated for $48 \mathrm{~h}$ in an incubator. The final cell population (day 2) was determined using the MTS assay: $20 \mu \mathrm{L}$ of MTS reagent was added to each well and incubated for $4 \mathrm{~h}$. The samples were then transferred to a clear tissue culture plate, and the absorbance at $490 \mathrm{~nm}$ measured using a SpectraMax ${ }^{\circledR} \mathrm{i} 3 \mathrm{x}$ microplate reader.

\subsection{Real-time $P C R$}

Quantitative real time PCR was used to examine mRNA transcription profiles in HCASMC incubated on native FN, or FN treated with HOCl $(1,10,50 \mu \mathrm{M})$. Multiple genes involved in cell mitosis, the inflammation response, and ECM synthesis and turnover were examined. Total RNA was extracted from HCASMC after $48 \mathrm{~h}$ incubation on native or HOCl-treated FN using an RNeasy Mini Kit (Qiagen). The RNA concentration and purity was quantified spectrophotometrically using a SpectraMax $^{\circledR}$ i3x microplate reader. RNA (400 ng) was used for single strand cDNA synthesis using a cDNA RT kit in a total volume of $20 \mu \mathrm{L}$ containing $1 \times$ RT reaction mix, $10 \times$ RT Enzyme Mix, and $2 \mathrm{U}$ RNase $\mathrm{H}$. Conditions for the reverse transcription reactions were as follow: $25^{\circ} \mathrm{C}$ for $10 \mathrm{~min}, 50{ }^{\circ} \mathrm{C}$ for $30 \mathrm{~min}$ and $85^{\circ} \mathrm{C}$ for $5 \mathrm{~min}$. Real-time PCR was carried out on ABI $7900 \mathrm{HT}$ machine with $20 \mu \mathrm{L}$ reaction mix buffer containing $10 \mu \mathrm{L}$ SYBR $^{\circledast}$ GreenER $^{\mathrm{TM}}, 2 \mu \mathrm{L}$ of each primer at $10 \mathrm{pmol} / \mu \mathrm{L}$, $0.4 \mu \mathrm{L}$ of ROX reference dye and $2 \mu \mathrm{L}$ of cDNA. Commercial primers were ordered form Qiagen without definite primer sequence (IL-6, TNF$\alpha$, COX-2, iNOS, IL-1 $\beta$, FN1, COL4A1, LAMA1, LAMA5, LAMB2), other primers were also used (5'-3'): PCNA (F: AGGCACTCAAGGACCTCA TCA; R: GAGTCCATGCTCTGCAGGTTT), CCNA1 (F: GCACCCTGCTCG TCACTTG; R: CAGCCCCCAATAAAAGATCCA), CCNB1 (F: AGCTGCTG CCTGGTGAAGAG; R: GCCATGTTGATCTTCGCCTTA), LAMA2 (F: GTT CCAGGGCATTTGTGTGA; R: TAGATGCTGGGTTTGGGCTTT), MMP1 (F: CGCACAAATCCCTTCTACCC; R: GGACTTCATCTCTGTCGGC), MMP11 (F: TCTACTGGAAGTTTGACCCTGTG; R: GTCAGAGGAAAGTGTTGG
CAG), MMP13 (F: TTTTTCAACGGACCCATACAGTT; R: TTACCCCAAA TGCTCTTCAGG), ADAMTS1 (F: CTTGTGGCAGACCAGTCGAT; R: TTC ACCACCACCAGGCTAAC), TIMP2 (F: TACACACGCCAATGAAACCGA; R: GGTTGCCGCTGAATAGAACA). $\beta$-actin (F: GATTCCTATGTGGGCGA CGA; R: AGTTGGTGACGATGCCGTG) was used as house-keeping gene. Triplicate wells were used and data analysis was carried out using the 2 $\triangle \Delta \mathrm{CT}$ method.

\subsection{Statistics}

Statistical analysis of MS data was performed by Student's $t$-test using SAS Enterprise Guide 7.1 (SAS Inc., USA). For other analyses, oneway ANOVA and Student's $t$-tests were performed on IBM SPSS 19.0 to examine statistical significance. Experiments were performed in triplicate and $P<0.05$ was considered significant.

\section{Results}

\subsection{Hypochlorous acid induces chlorination and oxidation of human plasma FN}

To investigate the effect of MPO-derived $\mathrm{HOCl}$ on human plasma $\mathrm{FN}$, samples of the protein were treated with either reagent $\mathrm{HOCl}$ (bolus addition of 0,100 , and $500 \mu \mathrm{M}$ ) or an $\mathrm{MPO}-\mathrm{H}_{2} \mathrm{O}_{2}-\mathrm{Cl}^{-}$enzymatic system with $500 \mu \mathrm{M} \mathrm{H}_{2} \mathrm{O}_{2}$. Modified and control samples were analysed by peptide mass mapping using mass spectrometry without reduction or alkylation as these interfere with the detection and quantification of some modifications, particularly chlorinations ([48]; T. Nybo, M.J. Davies, A. Rogowska-Wrzesinska, unpublished data). As no reduction step was employed, disulfide-linked peptides remain in the digestion mixture, resulting in a decreased overall coverage of the protein sequence. The disulfide-rich domains of FN (Heparin/Fibrin I, Collagen, and Fibrin II) account for the majority of the missing sequence coverage, with the total coverage being $\sim 66 \%$ in untreated control samples (Fig. 1). In contrast, near complete coverage was obtained for the DNA-, Cell-, and Heparin II- binding domains (Fig. 1).

Treatment of FN with 100 and $500 \mu \mathrm{M} \mathrm{HOCl}$ resulted in the detection of multiple modifications (Table 1 , Supplementary Tables 1,2), with only species detected in at least two out of three experimental treatments, and none of the controls, reported. A greater number, and a higher extent of modification, was detected with $500 \mu \mathrm{M} \mathrm{HOCl} \mathrm{com-}$ pared to the control, or $100 \mu \mathrm{M}$ treatment (Supplementary Figs. 1-5). Thus, with the lower oxidant dose, 6 modifications were detected at 6 different sites within the covered sequence, whereas with $500 \mu \mathrm{M} \mathrm{HOCl}$, 25 modifications were observed. In some cases, multiple modifications were detected within a single peptide (e.g. at Met, M, or Tyr, Y, in the peptide: VTIMWTPPESAVTGYR), or as a result of both mono- and dichlorination of a Tyr residue at a single site (e.g. at the first Tyr in the peptide: IYLYTLNDNAR). Three major types of modification were detected: oxidation of Met residues (3 sites: Met-926, Met-1783, Met2050 ) to give an $m / z+16$ species assigned to the sulfoxide, oxidation at Trp residues (5 sites: Trp-927, Trp-1195, Trp-1468, Trp-1742, Trp1923) to give an $m / z+16$ species, and mono- or di-chlorination at Tyr residues (16 sites: see Table 1 ). With the $100 \mu \mathrm{M}$ treatment only monochlorination (to give 3-ClTyr) at Tyr was detected, whereas with the $500 \mu \mathrm{M}$ dose, dichlorination to give $3,5-\mathrm{Cl}_{2} \mathrm{Tyr}$ was detected at two specific Tyr residues (Tyr-687 and Tyr-1882). In these cases monochlorination was detected at the lower $\mathrm{HOCl}$ dose, suggesting that these

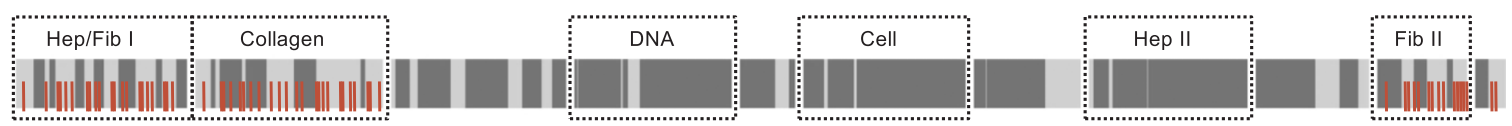

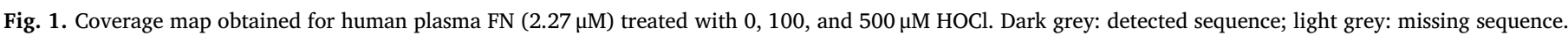

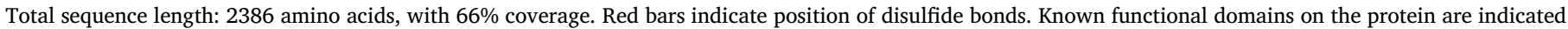
by boxes. 
Table 1

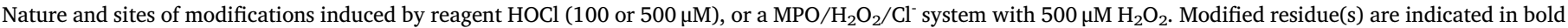

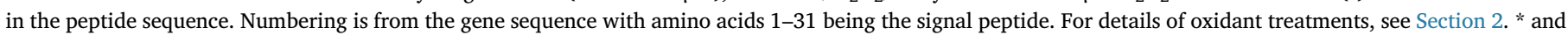
** indicate statistically significant differences to the untreated samples at the $\mathrm{p}<0.05$ and $\mathrm{p}<0.01$ levels respectively.

Modified residue Peptide residues Peptide sequence(s)

Modification detected Relative site occupancy of modifications Treatment

\begin{tabular}{|c|c|c|c|c|c|c|}
\hline Tyr-59 & $58-67$ & HYQINQQWER & 3-ClTyr & & $0.19^{*}$ & \\
\hline Trp-65 & $58-67$ & HYQINQQWER & Trp oxidation & & & $0.24^{* * *}$ \\
\hline Trp-484 & $480-487$ & IGDQWDK & Trp oxidation & & & $0.15^{* * *}$ \\
\hline Tyr-666 & $657-669$ & EATIPGHLNSYTIK & 3-ClTyr & & $1.04^{*}$ & \\
\hline Tyr-687 & $673-694$ & PGVVYEGQLISIQQYGHQEVTR & 3-ClTyr & $0.14^{* *}$ & $1.56^{* * *}$ & $0.28^{*}$ \\
\hline Tyr-687 & $673-694$ & PGVVYEGQLISIQQYGHQEVTR & $3,5-\mathrm{Cl}_{2} \mathrm{Tyr}$ & & $0.02^{* * *}$ & \\
\hline His-689 & $673-694$ & PGVVYEGQLISIQQYGHQEVTR & His oxidation & & & $0.31^{* * *}$ \\
\hline Met-926 & $923-938$ & VTIMWTPPESAVTGYR & Met or Trp oxidation & $11.74^{*}$ & $40.24 * *$ & \\
\hline Trp-927 & $923-953$ & VTIMWTPPESAVTGYRVDVIPVNLPGEHGQR & & & & \\
\hline Tyr-937 & $923-938$ & VTIMWTPPESAVTGYR & 3-ClTyr & & $0.12^{*}$ & \\
\hline Tyr-941 & $940-950$ & QYNVGPSVSK & 3-ClTyr & & 1.16 & $0.28^{* * *}$ \\
\hline Tyr-973 / Tyr-974 & 959-976 & NTFAEVTGLSPGVTYYFK & 3-ClTyr & $0.38^{* *}$ & $3.05^{* * *}$ & $0.63^{* * *}$ \\
\hline Tyr-1062 & $1055-1070$ & NLQPASEYTVSLVAIK & 3-ClTyr & & $0.07^{*}$ & \\
\hline Trp-1195 & $1170-1197$ & VVTPLSPPTNLHLEANPDTGVLTVSWER & Trp oxidation & & $2.56^{k * k}$ & \\
\hline Tyr-1206 & $1198-1207$ & STTPDITGYR & 3-ClTyr & & $3.30^{\text {*** }}$ & $0.04^{* * *}$ \\
\hline Trp-1468 & $1452-1476$ & DLEVVAATPTSLLISWDAPAVTVR & Trp oxidation & & $3.73^{k * *}$ & \\
\hline \multirow[t]{2}{*}{ Tyr-1538 } & $1525-1539$ & GDSPASSKPISINYR & 3-ClTyr & & $0.51^{k * k}$ & \\
\hline & 1533-1539 & PISINYR & & & & \\
\hline Trp-1742 & $1730-1753$ & FTQVTPTSLSAQWTPPNVQLTGYR & Trp oxidation & & $0.39^{* * *}$ & \\
\hline Tyr-1572 & $1562-1573$ & WLPSSSPVTGYR & 3-ClTyr & & $1.45^{* *}$ & $0.02^{* * *}$ \\
\hline \multirow[t]{2}{*}{ Met-1783 } & $1763-1787$ & TGPMKEINLAPDSSSVVVSGLMVATK & Met oxidation & $7.53^{* *}$ & $14.48^{k *}$ & $16.73^{\text {*** }}$ \\
\hline & $1767-1787$ & EINLAPDSSSVVVSGLMVATK & & & & \\
\hline Tyr-1788 & $1788-1797$ & YEVSVYALK & 3-ClTyr & & $1.03^{* * *}$ & \\
\hline Tyr-1793 & $1788-1797$ & YEVSVYALK & 3-ClTyr & & $1.03^{k * k}$ & $0.14^{* * *}$ \\
\hline Trp-1923 & $1911-1927$ & FLATTPNSLLVSWQPPR & Trp oxidation & & $0.18^{*}$ & \\
\hline Tyr-1879 & $1867-1880$ & SYTITGLQPGTDYK & 3-ClTyr & & $0.15^{*}$ & \\
\hline Tyr-1882 & $1881-1891$ & IYLYTLNDNAR & 3-ClTyr & $0.79^{*}$ & $6.08^{\text {k** }}$ & $1.73^{* * *}$ \\
\hline Tyr-1882 & $1881-1891$ & IYLYTLNDNAR & $3,5-\mathrm{Cl}_{2} \mathrm{Tyr}$ & & $0.14^{* * *}$ & $0.06^{* * *}$ \\
\hline \multirow[t]{2}{*}{ Met-2050 } & $2020-2058$ & TPFVTHPGYDTGNGIQLPGTSGQQPSVGQQMIFEEHGFR & Met oxidation & & $26.15^{* *}$ & \\
\hline & $2020-2059$ & TPFVTHPGYDTGNGIQLPGTSGQQPSVGQQMIFEEHGFRR & & & & \\
\hline Tyr-2076 & $2071-2091$ & HRPRPYPPNVGEEIQIGHIPR & 3-ClTyr & & $0.64^{* * *}$ & \\
\hline Tyr-2302 & $2301-2310$ & TYHVGEQWQK & 3-ClTyr & & $0.71^{\text {*** }}$ & $0.08^{* * *}$ \\
\hline
\end{tabular}

residues are particularly prone to modification.

Treatment with the MPO- $\mathrm{H}_{2} \mathrm{O}_{2}-\mathrm{Cl}^{-}$system, using $500 \mu \mathrm{M} \mathrm{H}_{2} \mathrm{O}_{2}$, also resulted in the detection of multiple modifications (Table 1 ). This system gives near stoichiometric conversion of $\mathrm{H}_{2} \mathrm{O}_{2}$ to $\mathrm{HOCl}$, as assessed by either the MCD or TMB assays (Supplementary Fig. 6). The modifications induced by the enzyme system reproduced some, but not all, of the modifications detected with the $500 \mu \mathrm{M} \mathrm{HOCl}$ system. Thus, 8 of the 3-ClTyr, and 1 of the 3,5- $\mathrm{Cl}_{2}$ Tyr, sites were reproduced. For Met oxidation, one site was reproduced (Met-1783), but two Trp oxidation sites (Trp-65, Trp-484) and one His (His-689) oxidation $(m / z+16)$ were also detected.

In some cases, multiple modifications were detected in close proximity within particular peptides, or regions of the sequence. Thus, Fig. 2 shows the fragment ion spectra of the peptide ${ }_{923}$ VTIMWTPPESAVTGYR $_{938}$ which was detected with modifications (oxidations) at Met-926 and Trp-927, and chlorination at Tyr-937. This cluster of damage was not detected with the MPO- $\mathrm{H}_{2} \mathrm{O}_{2}-\mathrm{Cl}^{-}$system. These modifications occurred both independently, producing peptide forms with each modification individually, and also as co-occurring species. The site assignment of the oxidation is determined by a +16 Da mass shift on either fragment ion $\mathrm{y}_{12}$ for Trp-927 or $\mathrm{y}_{13}$ for Met-926. Observation of predominantly no-mass shift $\mathrm{y}_{12}$ and a lower abundance of the mass shifted $\mathrm{y}_{12}$-ion indicate that Trp-927 is modified to some extent, but Met-926 is the primary target.

Quantification of the extent of modification at particular sites was assessed by determining the relative site occupancy (RSO). Overall, FN was modified to a lesser extent by the MPO enzymatic system when compared to the $500 \mu \mathrm{M}$ reagent $\mathrm{HOCl}$ system, both in number of sites and in relative site occupancy. A number of these modifications occur in functionally-important domains (Fig. 3). Thus, oxidation of Met-1783 was detected with both $500 \mu \mathrm{M} \mathrm{HOCl}$ and the MPO- $\mathrm{H}_{2} \mathrm{O}_{2}-\mathrm{Cl}^{-}$system, and to a lesser extent with $100 \mu \mathrm{M} \mathrm{HOCl}$ (Fig. 4A and C). For Tyr-1882, 3-ClTyr was observed with $100 \mu \mathrm{M} \mathrm{HOCl}$, while at $500 \mu \mathrm{M} \mathrm{HOCl}$ further chlorination to form $3,5-\mathrm{Cl}_{2} \mathrm{Tyr}$ was detected, as well as significantly higher levels of 3-ClTyr (Fig. 4B and D). Interestingly, no chlorination was observed on the nearby Tyr-1884 residue. Summation of all of the relative site occupancy data for 3-ClTyr formation gives values of $\sim 1.3$, $\sim 22.1$ and $\sim 3.2$ for the $100 \mu \mathrm{M} \mathrm{HOCl}, 500 \mu \mathrm{M} \mathrm{HOCl}$ and MPO enzymatic systems respectively. Inclusion of all the observed modifications (i.e. chlorination at Tyr and oxidations at Met, Tyr, His and Trp) gives values of $\sim 20.6, \sim 110.0$ and $\sim 20.7$ for the $100 \mu \mathrm{M} \mathrm{HOCl}, 500 \mu \mathrm{M}$ $\mathrm{HOCl}$ and MPO systems respectively.

\subsection{Quantification of total 3-chlorotyrosine}

The total extent of 3-ClTyr formation with reagent $\mathrm{HOCl}$ was determined by complete hydrolysis of the native and modified proteins by acid hydrolysis, and subsequent separation and quantification of the released 3-ClTyr by LC-MS, using an isotope-labelled product as an internal standard [47]. Under the conditions used the concentration of 3 -ClTyr detected on the untreated protein was $\sim 9.7 \mu$ moles 3 -ClTyr per mole protein, and $\sim 0.97$ mmoles 3-ClTyr per mole parent Tyr, based on the presence of 100 Tyr residues in parent FN. Treatment of the FN with $100 \mu \mathrm{M} \mathrm{HOCl}$ increased the 3-ClTyr levels $\sim 30$-fold (i.e. $\sim 28.5$ mmoles 3-ClTyr per mole parent Tyr), and treatment with $500 \mu \mathrm{M} \mathrm{HOCl}$ increased the 3-ClTyr levels 141-fold (i.e. $~ 137$ mmoles 3-ClTyr per mole parent Tyr). These correspond to \% conversions (after subtraction of control values) of $\sim 2.8$ and $\sim 13.7$ for 3 -ClTyr formation from the 


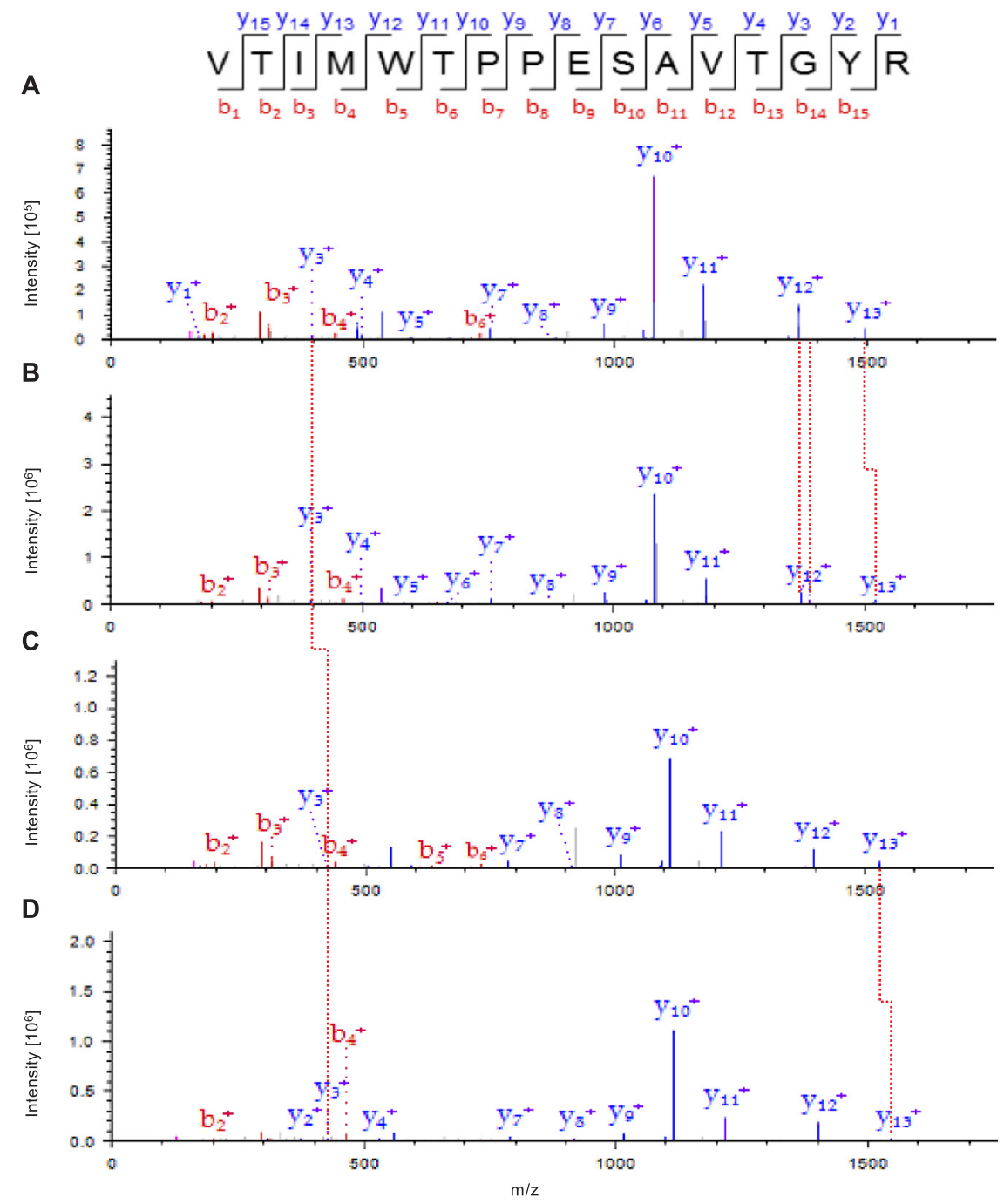

Fig. 2. Fragment ion spectra from four native and modified forms of the peptide ${ }_{923} V_{T I M W T P P E S A V T G Y R}{ }_{938}$ from human plasma FN treated with $500 \mu \mathrm{M}$ HOCl. (A) Native peptide; (B) single oxidation at Met-926 and to lesser extent at Trp-927; (C) single chlorination of Tyr-937; (D) simultaneous oxidation at Met-926 and chlorination at Tyr-937. The oxidations result in +16 Da mass shift on ions $\mathrm{y}_{12}$ (for oxidation at Trp-927) and $\mathrm{y}_{13}$ (for oxidation at Met-926). The chlorination at Tyr937 is indicated by the +34 Da mass shift of the $y_{3}$ ion. These mass shifts are indicated by the red lines. For fragment ion masses see Supplementary Fig. 3.
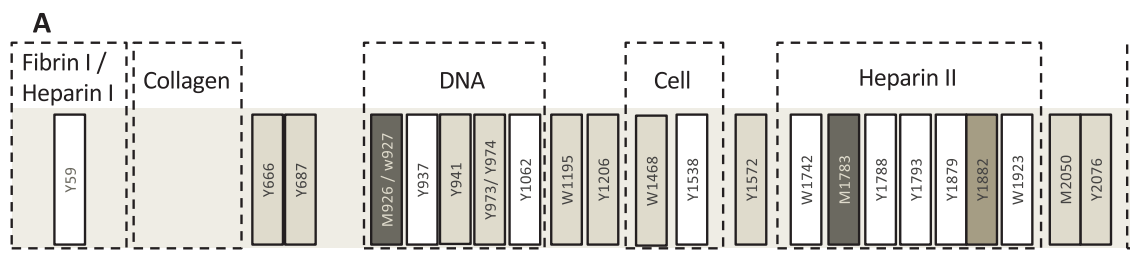

\section{B}
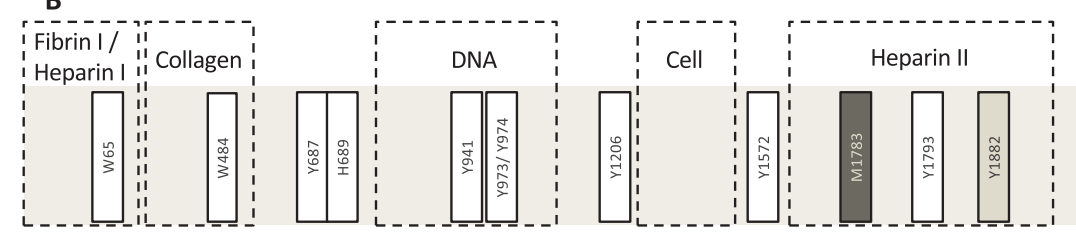

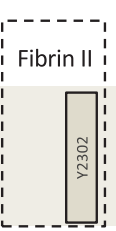

Fig. 3. Schematic of the functional domains of human plasma $\mathrm{FN}$, sites of modification (Table 1) and relative site occupancies (\% modification) after treatment with (A) $500 \mu \mathrm{M}$ $\mathrm{HOCl}$, or (B) exposure to $\mathrm{MPO} / \mathrm{H}_{2} \mathrm{O}_{2} / \mathrm{Cl}^{-}$with $500 \mu \mathrm{M} \mathrm{H}_{2} \mathrm{O}_{2}$. For further details, see Materials and methods. $\mathrm{M}=$ Met, $\mathrm{H}=$ His, $\mathrm{W}=$ Trp, $\mathrm{Y}$ $=$ Tyr. Modifications $(m / z+16)$ detected at $\mathrm{M}, \mathrm{H}, \mathrm{W}$ are assigned to mono-oxidation. Modifications at $\mathrm{Y}$ were single or double chlorinations to give $3-\mathrm{ClTyr}$ or $3,5-\mathrm{Cl}_{2} \mathrm{Tyr}$. 
A

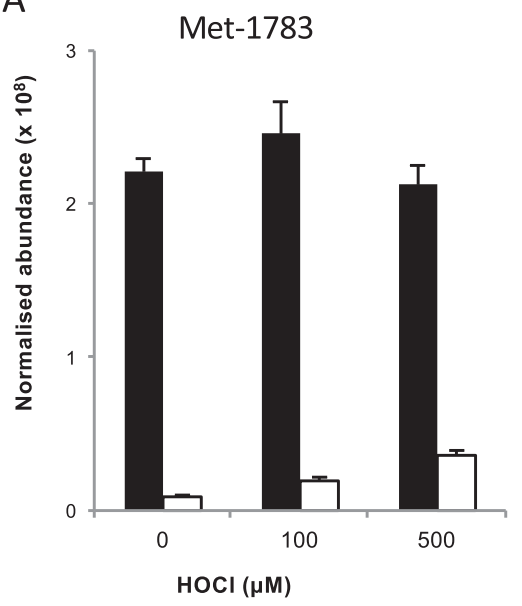

C

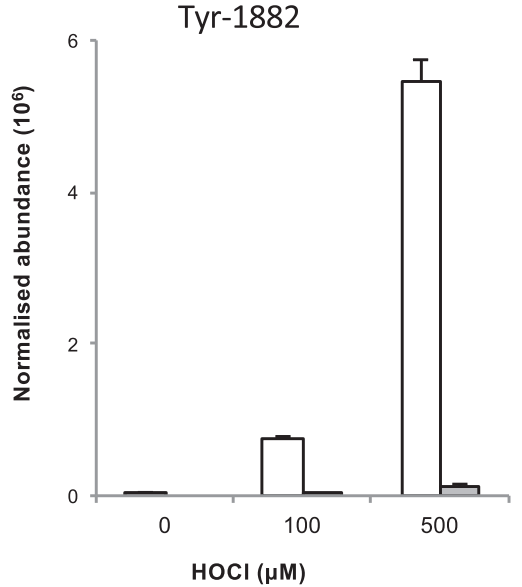

B

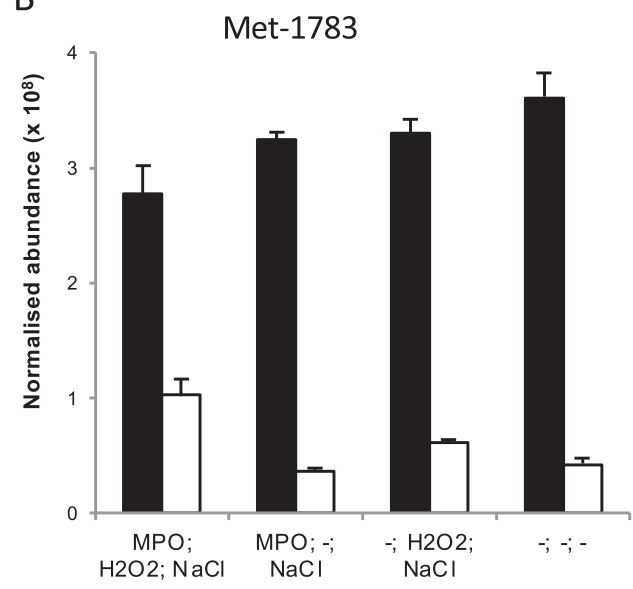

D

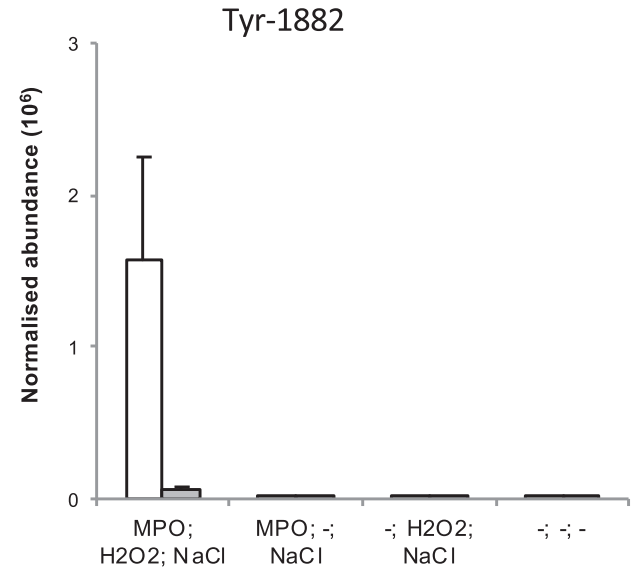

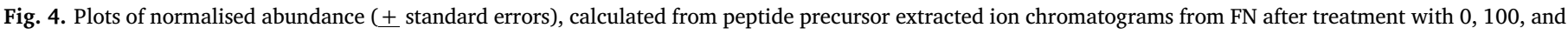

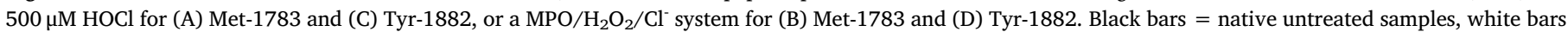

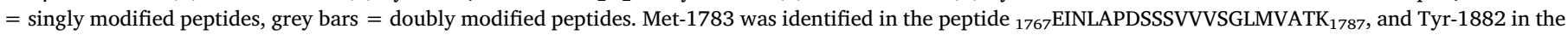
peptide ${ }_{1881}$ IYLYTLNDNAR $_{1891}$ (Table 1). For further details, see Materials and methods.

total Tyr population present in the FN sequence, by 100 and $500 \mu \mathrm{M}$ $\mathrm{HOCl}$ respectively (cf. the values of $\sim 1.3$ and $\sim 22.1$ described above for the more limited number of Tyr residues detected in the FN sequence by mass spectrometry).

\subsection{Increased heparin affinity of HOCl-modified FN}

As modifications were detected as residues within FN functional domains (Fig. 3), further analyses were carried out to examine the potential importance of these modifications. As multiple modifications (Trp-1742, Met-1783, Tyr-1788, Tyr-1793, Tyr-1879, Tyr-1882, Trp1923) were detected within the Heparin-II domain (residues 1721-1991), the impact of these modifications on the ability of FN to bind heparin was determined by heparin affinity chromatography (Fig. 5). The elution time of native FN ( $8.13 \mathrm{~min})$ was significantly shorter from those for FN pre-treated with $100 \mu \mathrm{M} \mathrm{HOCl}(8.2 \mathrm{~min}$ ) or $500 \mu \mathrm{M} \mathrm{HOCl}$ ( $8.32 \mathrm{~min}$ ) (Fig. 5), consistent with a stronger binding of the modified FN to the heparin molecules present in the column.

3.4. Fibronectin modified by $\mathrm{HOCl}$ or a $\mathrm{MPO}-\mathrm{H}_{2} \mathrm{O}_{2}-\mathrm{Cl}^{-}$system gives rise to altered adhesion and proliferation of primary human coronary artery smooth muscle cells (HCASMC)

To examine the impact of oxidant-induced changes on FN, studies were carried out in which pure cultures of primary human coronary artery smooth muscle cells (HCASMC) were added to tissue culture plates containing native or pre-modified FN. Thus, HCASMC were incubated on native or $\mathrm{HOCl}$-modified $\mathrm{FN}$ for $90 \mathrm{~min}$ at $37^{\circ} \mathrm{C}$ in a cell incubator before removal of non-adherent cells by washing, and subsequent staining with trypan blue and examination by bright field microscopy (Fig. 6A, top row). Alternatively, cells were added to FNcoated glass culture slides that had been pre-exposed to HOCl (20 or $100 \mu \mathrm{M}$ ) for $2 \mathrm{~h}$ at $37^{\circ} \mathrm{C}$. The adherent HCASMC were then visualized by staining for F-actin and the nucleus, and fluorescence microscopy (Fig. 6A, bottom row). The HCASMC showed a characteristic spread spindle shape on native FN, but were less spread and were typically "rounded up" on HOCl-treated FN, indicative of poor adherence to oxidized FN. Quantification of cell adherence was carried out using HCASMC, pre-loaded with the fluorescent dye Calcein-AM, incubated on native or HOCl-modified FN ( 90 mins, $37^{\circ} \mathrm{C}$ ), non-adherent cells removed by washing, and quantification of the number of adherent cell by fluorescence. Using this approach, and with native FN taken as $100 \%$, a statistically-significant decrease in cell adherence was detected on pre-treatment of the FN with $10 \mu \mathrm{M}$ or greater concentrations of $\mathrm{HOCl}$, with this occurring in a dose-dependent manner (Fig. 6B).

Experiments with an MPO- $\mathrm{H}_{2} \mathrm{O}_{2}-\mathrm{Cl}^{-}$system with $20 \mathrm{nM} \mathrm{MPO}$, $200 \mathrm{mM} \mathrm{Cl}^{-}$and varying amounts of $\mathrm{H}_{2} \mathrm{O}_{2}$, reproduced the effects of reagent $\mathrm{HOCl}$. Thus, pre-treatment of FN with the enzyme system decreased HCASMC adhesion to the modified FN, relative to native FN, with this occurring in a dose-dependent manner with increasing $\mathrm{H}_{2} \mathrm{O}_{2}$ 
A

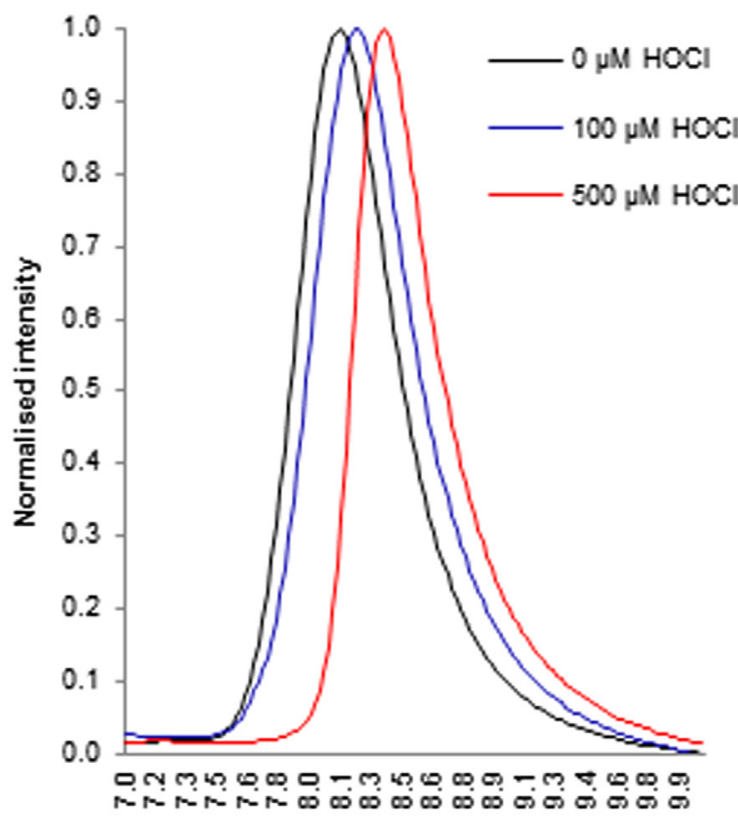

Retention time [min]
B

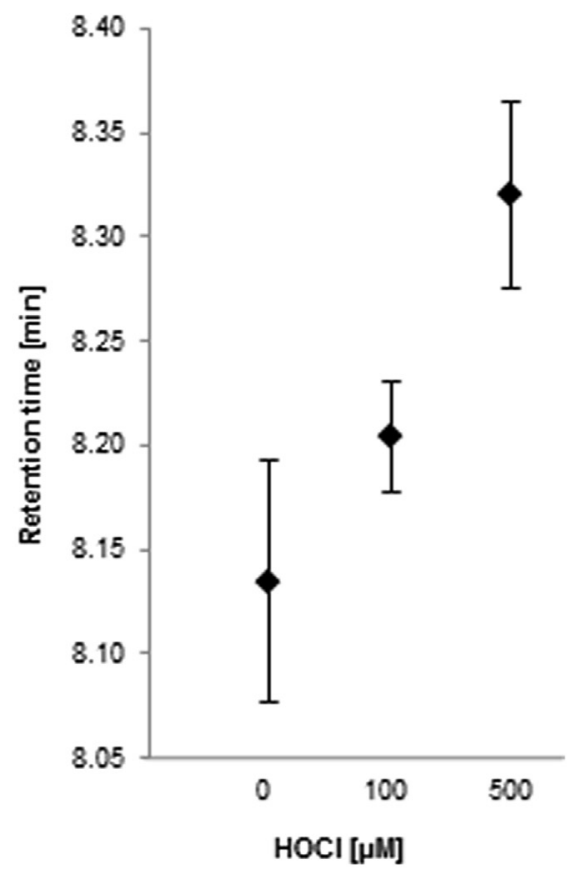

Fig. 5. Heparin-affinity chromatography of human plasma FN $(2.27 \mu \mathrm{M})$, either native (no $\mathrm{HOCl}$ treatment), or after modification with 100 or $500 \mu \mathrm{M}$ $\mathrm{HOCl}$. The peaks in (A) were normalised to equal intensity, and are representative data. (B) Plot of mean elution times ( + standard errors) from 3 independent experiments. Black line: native $\mathrm{FN}$; blue line: treatment with $100 \mu \mathrm{M} \mathrm{HOCl}$; red line: treatment with $500 \mu \mathrm{M} \mathrm{HOCl}$. For further details, see Materials and methods. concentrations, with statistical differences detected at $1 \mu \mathrm{M}$ or greater concentrations of $\mathrm{H}_{2} \mathrm{O}_{2}$ (Fig. $6 \mathrm{C}$ ).

Further studies examined the subsequent proliferation of HCASMC adhered to the native and modified FN. In these experiments, the cells were allowed to adhere to the native or HOCl-modified FN (pre-treated with $1 \mu \mathrm{M} \mathrm{HOCl}$ to ensure significant numbers of adherent cells), and then allowed to proliferate for $48 \mathrm{~h}$ in standard growth medium. After this period, the number of metabolically active cells was determined using the MTS assay. Due to the differing initial numbers of cells at the beginning of the proliferation phase (see data above), the data were corrected for this parameter by plotting the fluorescence intensity at day zero against the values obtained from the MTS assay at day 2 . The resulting data (Fig. 7A) show that the gradient of the plots for the oxidant-modified FN were greater than that for the native FN (red dots versus blue dots) indicating that the cells proliferated more rapidly on the oxidant-treated FN. These data are quantified in Fig. 7B as a normalised proliferation rate.

3.5. Fibronectin modified by $\mathrm{HOCl}$ or a $\mathrm{MPO}-\mathrm{H}_{2} \mathrm{O}_{2}-\mathrm{Cl}^{-}$system gives rise to altered gene expression in human coronary artery smooth muscle cells (HCASMC)

As the data presented above are consistent with decreased adherence, but a subsequent increased rate of HCASMC growth, on oxidant-modified FN, the expression of a number of mitosis-related genes were examined in the HCASMC cultured on native versus HOCl-treated FN. mRNA was collected from cells incubated on the native and modified FN at day 2 after adhesion (see preceding section) and analysed for the fold-change in PCNA (Proliferating Cell Nuclear Antigen), CCNA 1 (Cyclin-A1) and CCNB 1 (Cyclin-B1) by RT-PCR with $\beta$-actin used as a housekeeping gene. Significantly-elevated levels of these genes were detected for the cells exposed to the FN pre-treated with all three concentrations of $\mathrm{HOCl}$ examined $(1,10$ and $50 \mu \mathrm{M})$, compared to native FN, with the greatest increases $(\sim 4.7$-fold $)$ seen for PCNA after treatment of the FN with $1 \mu \mathrm{M} \mathrm{HOCl}$ (Fig. 8). Lower, but significantlyelevated expression $(\sim 3$-fold) was detected with higher $\mathrm{HOCl}$ concentrations. An approximate doubling of the expression of CCNA 1 and
CCNB 1 was seen with all of the FN samples pre-treated with the different $\mathrm{HOCl}$ concentrations, with no statistical differences detected between the different concentrations (Fig. 8).

In addition to changes in mitosis-related genes, potential changes in the expression of inflammation, ECM proteins and ECM-modifying enzymes (matrix metalloproteinases, MMPs, and tissue inhibitor of matrix metalloproteinases 2, TIMP2) were examined for the cells exposed to the HOCl-modified FN (as above) compared to native FN. The resulting data is shown as a heat map relative to the native FN data on a log scale in Fig. 9.

Exposure of the cells to FN modified with different concentrations of HOCl $(1 \mu \mathrm{M}, 10 \mu \mathrm{M}, 50 \mu \mathrm{M})$, compared to native $\mathrm{FN}$, resulted in increased mRNA expression of $I L-6(P<0.05)$, with this mirrored by a small, but significant, increase in the level of IL- 6 protein, detected by ELISA, in the conditioned cell media from the cultured HCASMC (Supplementary Fig. 7), with this occurring in a dose-dependent manner with increasing HOCl-exposure of the FN. The mRNA levels of iNOS were also significantly elevated $(P<0.05)$ at all HOCl-concentrations tested, whereas only small changes were detected with $I L-1 \beta$ and $\mathrm{COX}-2$ (Fig. 9).

Gene expression for multiple ECM proteins, including $F N$ and LAMA1 were significantly up-regulated $(P<0.05)$, while the expression of LAMB2 was markedly down-regulated $(P<0.05)$, with these changes being more marked at the higher concentrations of HOCl (10 and $50 \mu \mathrm{M}$ ) (Fig. 9). Less marked changes were detected in the mRNA levels of the other matrix proteins examined (Fig. 9). Significant upregulation of mRNA of a number of MMPs known to be involved in ECM remodelling, was also detected (Fig. 9). Significant increases were detected, particularly for MMP8, MMP11 and MMP13, for HCASMC incubated on FN modified with $10 \mu \mathrm{M}$ and $50 \mu \mathrm{M} \mathrm{HOCl}$, with this extending down to the $1 \mu \mathrm{M} \mathrm{HOCl}$ treatment for MMPs 11 and 13. These data are consistent with a range of cellular responses including increased expression of new matrix proteins, and an attempted remodelling of the ECM surrounding the cells in response to oxidantmediated changes to the FN to which the cells are attached. 
(A)

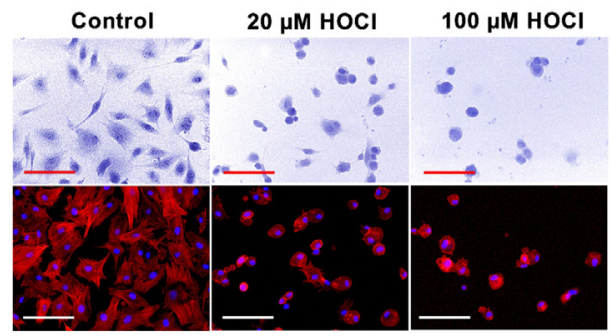

(B)
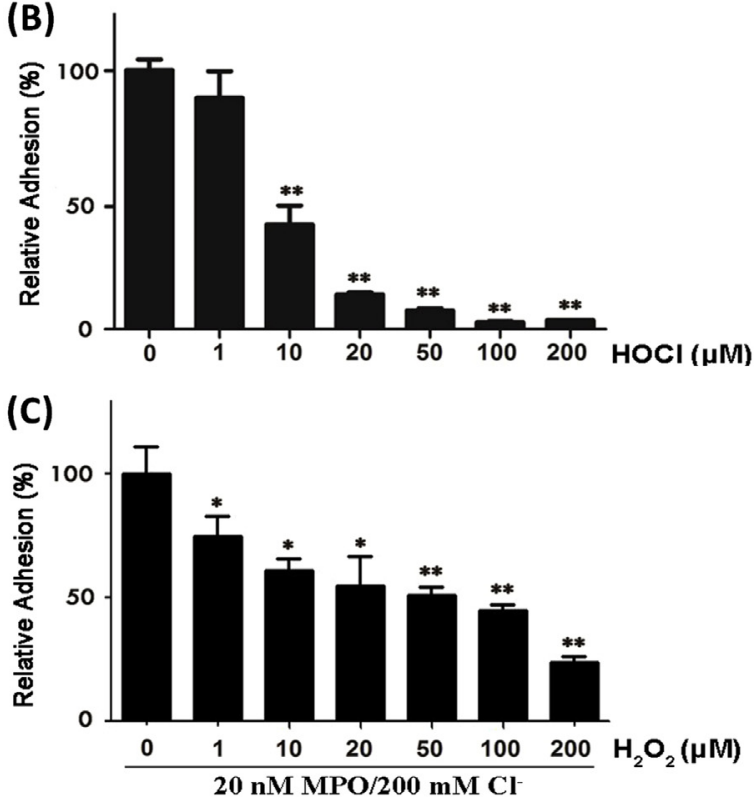

Fig. 6. Effect of pre-treatment of FN with $\mathrm{HOCl}$ (panels A, B) or $\mathrm{MPO} / \mathrm{H}_{2} \mathrm{O}_{2} / \mathrm{Cl}^{-}$ with the indicated concentrations of $\mathrm{H}_{2} \mathrm{O}_{2}$ (panel C), on subsequent adhesion of primary human coronary artery smooth muscle cells (HCASMC). Panel (A), top row: HCASMC incubated with trypan blue imaged at 20-fold magnification using bright field microscopy. Panel (A), bottom row: Adherent cells on native or HOCl-treated FN stained for F-actin fibres and nuclei and imaged using fluorescence microscopy. Panels (B, C), Quantification of adhewrent HCASMC pre-loaded with $5 \mu \mathrm{M}$ calcein $\mathrm{AM}$ with subsequent fluorescence detection. For further details see Materials and methods.

\section{Discussion}

In this study, we have identified and quantified sites of oxidation and chlorination on the major extracellular matrix protein fibronectin (FN), induced by the inflammatory oxidant $\mathrm{HOCl}$, when added as a reagent, or generated by a $\mathrm{MPO}-\mathrm{H}_{2} \mathrm{O}_{2}-\mathrm{Cl}^{-}$enzyme system. The plasma

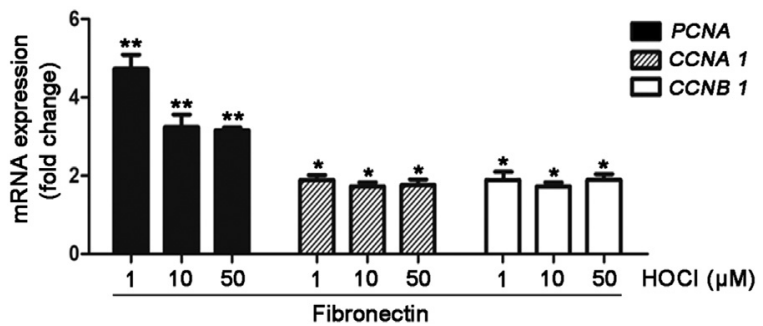

Fig. 8. Effect of HOCl-treated FN, compared to parent FN, on mRNA expression of mitosis-related genes in HCASMC. HCASMC were incubated on native or HOCl-treated $(1,10$ or $50 \mu \mathrm{M} \mathrm{HOCl}$ ) fibronectin in 24 -well plates for $48 \mathrm{~h}$ (as described in the legend to Fig. 7) before RNA was extracted for cDNA synthesis and real time PCR. For further details, see Materials and methods.

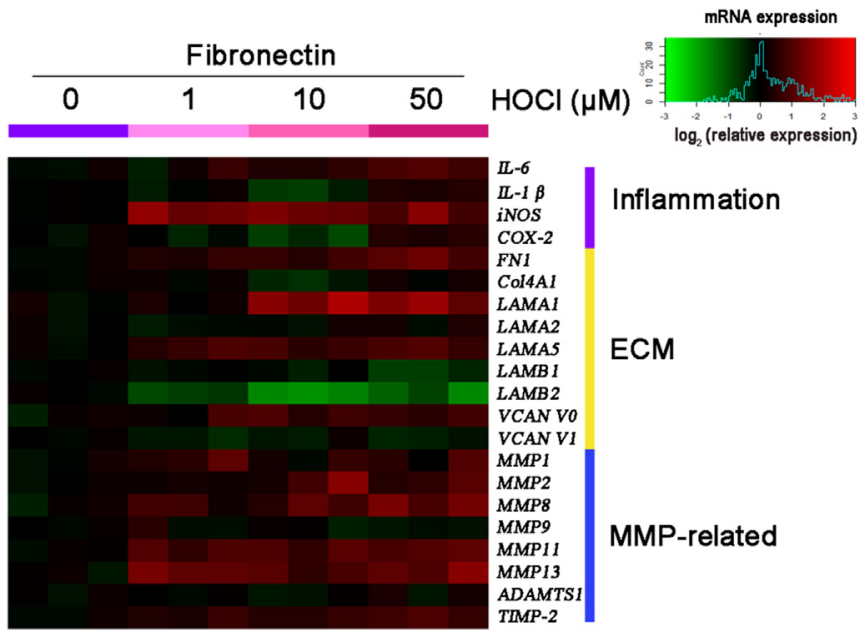

Fig. 9. Effect of HOCl-treated FN (1, 10 or $50 \mu \mathrm{M} \mathrm{HOCl})$, compared to parent FN, on mRNA expression of mitosis-related genes in HCASMC. HCASMC were incubated on native or HOCl-treated fibronectin for $48 \mathrm{~h}$ before RNA extraction, cDNA synthesis and real time PCR. The heat map indicates changes in expression on a log scale with green colouration indicating down-regulation, and red colouration indicating up-regulation. The genes examined include those involved in inflammation (purple), extracellular matrix proteins (ECM, yellow) and matrix metalloproteinases (MMP) and a MMP inhibitor (TIMP-2) (MMPrelated: blue). For further information see main text and Materials and methods.

form of FN plays a key role in the early physiological responses to tissue injury as it binds to fibrin and is a component of blood clots [3]. The fibrin-FN network is critical to the adhesion, migration and proliferation of fibroblast and endothelial cells and therefore tissue repair,

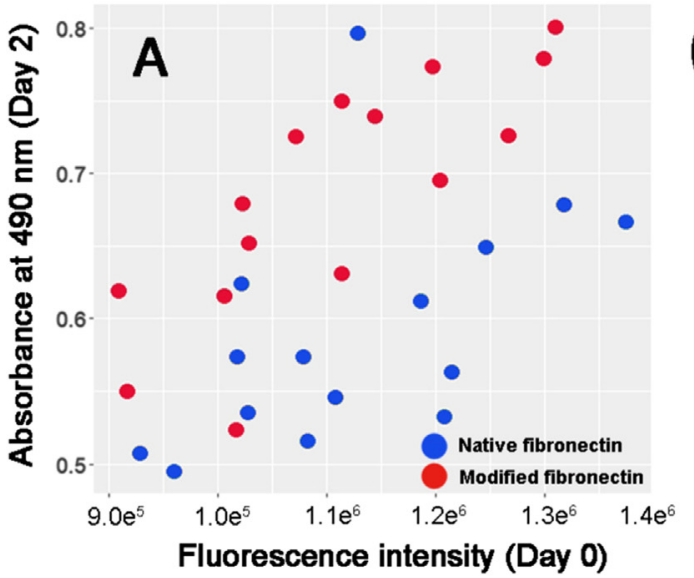

(B)

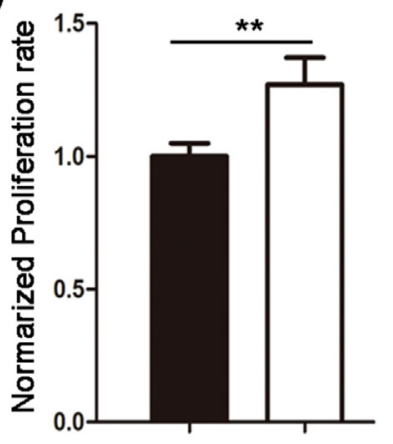

Fibronectin
Fig. 7. Effect of pre-treatment of FN with reagent $\mathrm{HOCl}$ $(1 \mu \mathrm{M})$ on subsequent proliferation of adherent primary human coronary artery smooth muscle cells (HCASMC). Panel (A), HCASMC (pre-loaded with $5 \mu \mathrm{M}$ calcein AM) were added to untreated FN, or FN pre-treated with $1 \mu \mathrm{M}$ $\mathrm{HOCl}$ and washed to remove excess oxidant. Adherent cells were quantified by fluorescence. The cells were then incubated for $48 \mathrm{~h}$ in growth medium and the final cell population determined by MTS assay. (B) The proliferation rate of HCASMC for both groups displayed as the ratio of normalised cell populations at 0 and $48 \mathrm{~h}$. For further details, see Materials and methods. 
including within the artery wall $[4,5]$. FN is present in the arterial wall under normal physiological conditions [7], but increased concentrations, and altered isoforms, are present in atherosclerotic lesions [8] with this changing during lesion development [9]. Increased lesion FN levels are mirrored by increases in plasma FN in people with coronary artery disease [10], with this ascribed to remodelling of the damaged vascular wall and ECM deposition in the fibrous caps of lesions [11]. The extent of such ECM deposition has been reported to be a critical factor in lesion stability and propensity to rupture, and therefore the occurrence of heart attacks and strokes [11]. Previous studies have provided data consistent with damage to, and destabilization of, components of atherosclerotic plaques by oxidants generated by inflammatory cells $[17,18]$, with oxidant-mediated damage detected on ECM perlecan [49,50], laminin [51], (tropo)elastin [52] and fibronectin [53] in human atherosclerotic lesions, as well as lesion lipoproteins (e.g. $[36,37,39,54])$. Evidence has been presented a role for both peroxynitrous acid $\left(\mathrm{ONOOH}\right.$, from reaction of $\mathrm{O}_{2}{ }^{--}$with $\mathrm{NO}$; reviewed [55]) as well as MPO-derived HOCl [29,56,57].

Despite the reported importance of ECM damage and lesion destabilization by oxidants, there is limited information on the modifications induced by $\mathrm{HOCl}$ on isolated $\mathrm{FN}$, or FN in the arterial wall, though it is well established that FN is a target for $\mathrm{HOCl}[26-28,57]$. There is however, considerable evidence for the presence of elevated and enzymatically active MPO in human atherosclerotic lesions, with this being localized in regions prone to rupture [23], and modified FN colocalizes with MPO in human atherosclerotic lesions [29]. Elevated MPO levels have been reported, in a large number of studies, to be both diagnostic and prognostic of major adverse cardiovascular events (e.g. [25,58-63]).

In addition to altering the composition and structure of FN, oxidantdamage may also affect FN function, particularly with regard to ECM assembly, due to the key role that this protein plays in interacting with other matrix proteins (cf. the fibrin, heparin, and collagen-binding sites on FN). FN modifications may also affect cell-ECM interactions due to the presence of a both a cell binding (RGD) site which interacts with cellular integrin ( $\alpha 5 \beta 1)$ proteins, and a binding site for vascular endothelial growth factor (VEGF) within the Hep II binding site (in the $\mathrm{III}_{13}$ and $\mathrm{III}_{14}$ modules) which plays a key role in endothelial cell migration and proliferation [1]. Recent studies have shown that primary human coronary artery endothelial cells (HCAEC) show decreased adhesion and proliferation on FN modified by both $\mathrm{HOCl}$ and a MPO$\mathrm{H}_{2} \mathrm{O}_{2}-\mathrm{Cl}^{-}$enzyme system, with this being associated with damage to specific FN epitopes including the cell-binding region [57].

$\mathrm{HOCl}$ preferentially targets sulfur-containing amino acids (Cys, Met and cystine) $[22,30,31]$, but can also modify His, Trp, Lys and Tyr residues to a significant extent [22]. The formation of 3Cl-Tyr from reaction with Tyr residues has been used to elucidate the role of MPO and $\mathrm{HOCl}$ in tissue damage as this product is a stable, distinctive and wellestablished biomarker of HOCl-mediated damage [34-36].

The data presented here indicates that both reagent $\mathrm{HOCl}$ and the MPO- $\mathrm{H}_{2} \mathrm{O}_{2}-\mathrm{Cl}^{-}$system can generate significant, but selective, damage on $\mathrm{FN}$, and that these changes induce significant functional alterations with regard to smooth muscle cell adhesion, proliferation, gene expression and phenotype. The enzyme system was provided with $500 \mu \mathrm{M}$ $\mathrm{H}_{2} \mathrm{O}_{2}$ in order to generate $\sim 500 \mu \mathrm{M} \mathrm{HOCl}$ to allow direct comparison between the reagent and enzyme systems, and hence any potential localization or other effects induced by the enzyme.

Of the residues expected to react with $\mathrm{HOCl}$ and $\mathrm{MPO}-\mathrm{H}_{2} \mathrm{O}_{2}-\mathrm{Cl}^{-}$ system $[22,30,64]$, a high proportion were present in the peptide sequences detected by the MS mapping. Of the 26 Met residues present in the human plasma FN sequence (UniProt - P02751), 14 were observed by MS, with 27 of 39 detected for Trp, 33 from 55 for His, and 64 from 100 for Tyr. Of these residues only 3 Met, 7 Trp, 1 His and 16 Tyr residues were detected as targets for oxidation (in the case of Met, Trp and His) or chlorination (Tyr), when exposed to reagent $\mathrm{HOCl}$ (100 or $500 \mu \mathrm{M}$ ) or the MPO- $\mathrm{H}_{2} \mathrm{O}_{2}-\mathrm{Cl}^{-}$system. This corresponds to modification levels of $\sim 11.5, \sim 12.8, \sim 2.0$ and $\sim 15.0 \%$ for Met, Trp, His and Tyr respectively when considered as a $\%$ of the full sequence total, and $\sim 21.4, \sim 25.9, \sim 3.0$ and $\sim 23.4 \%$, respectively, of the Met, Trp, His and Tyr residues detected. The similarity of these percentages for Met, Trp and Tyr, suggest that factors other than the absolute reactivity of a particular type of residue with $\mathrm{HOCl}$ (which decreases in the order Met $>>$ Trp $>$ Tyr; $[22,30,64]$ ) must play a role in determining which sites are modified.

Summation of the extents of 3-ClTyr formation detected by both MS and the amino acid analyses, indicates that between $13 \%$ and $22 \%$ of the Tyr residues are modified by $500 \mu \mathrm{M} \mathrm{HOCl}$, and hence $\sim 1$ in $5 \mathrm{FN}$ molecules contains a 3Cl-Tyr residue after this treatment. The overall extent of modification (i.e. including oxidation) was considerably higher (primarily driven by the high extent of Met modification), with $\sim 1$ in 5 FN molecules carrying a modification after treatment with $100 \mu \mathrm{M} \mathrm{HOCl}$ or the MPO system, and all $(\sim 110 \%)$ FN molecules, on average, containing a single modification after treatment with $500 \mu \mathrm{M}$ $\mathrm{HOCl}$.

These site occupancy data indicate that only a subset of the residues detected by MS are detected in a modified form, and hence it is likely that some residues are much more susceptible to modification than others. Therefore, as the sequence coverage was only $\sim 66 \%$, there may be modifications to significantly more residues within the non-detected portions of the sequence. However the relative similarity of the data between the MS and total amino acid analyses suggest that a reasonably similar extent of modification must also be occurring in the non-observed regions of the sequence. Most of the "missing" sequence is comprised of the cystine (disulfide)-rich Hep I/Fibrin I, Collagen, and Fibrin II domains of FN. These regions are difficult to detect using the current protocol as a result of the absence of a reduction and alkylation steps which remove the disulfide bonds and thereby release these peptides. This protocol was however employed as reduction and alkylation have been shown to cause artefactual loss of modification sites ([48]; T. Nybo, M.J. Davies, A. Rogowska-Wrzesinska, unpublished data).

Comparison of the data obtained with $500 \mu \mathrm{M} \mathrm{HOCl}$ and the MPO system shows a similar pattern of chlorination but fewer sites, and lower extents, of modification, with only 8 of the 16 Tyr chlorinations seen with $\mathrm{HOCl}$, reproduced by the MPO system. Oxidation was observed at 4 residues with the enzyme system $(2 \times \operatorname{Trp}, 1 \times$ His, $1 \times$ Met) compared to 7 with $\mathrm{HOCl}$, though the position and nature of the residues affected were significantly different for the oxidized residues when compared to the chlorination sites (Table 1). These findings indicate that there are differences in the selectivity of damage between reagent $\mathrm{HOCl}$ and the enzyme system with regard to the susceptibility of certain sites to modification. The overall extent of modification was also lower for the MPO system than reagent HOCl; this is perhaps understandable due to the presence of additional protein in the enzyme system (in the form of the MPO), which will also be a target for HOCl. Indeed, a number of MPO-derived peptides containing oxidation sites were detected in the enzyme experiments, though these were not analysed in detail (Nybo et al., unpublished data).

The reasons for the (apparent) altered specificity of damage observed with the enzyme system is unclear. The majority of the differences are present in the N-terminal portion of FN, which appears to be exclusively modified by the MPO-system, with this possibly due to association of the enzyme with one or more domains within this part of FN. Thus, oxidation of Trp- 65 and Trp- 484 were detected in the $I_{1}$ and $\mathrm{I}_{7}$, modules, while oxidation at His-689 was also detected in module $\mathrm{III}_{1}$. Furthermore, the absence of significant modification of Met- 926 by the MPO system, which is significantly modified by reagent $\mathrm{HOCl}$, is consistent with an altered conformation or accessibility of this residue in the presence of MPO, compared to its absence. It has been reported previously that MPO binds to FN [65], though MPO activity was reported to increase after binding to FN in cell-derived ECM $[65,66]$, and the exact site of interaction has not been established. Our observations 
(A)

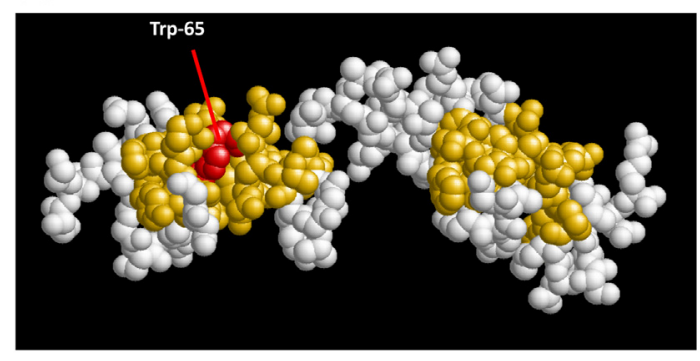

(B)

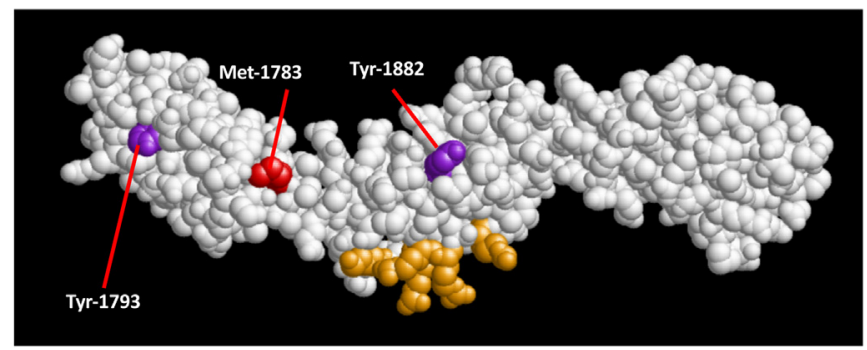

Fig. 10. Rendering of partial crystal structures of the Heparin/Fibrin I (PDB: 109A; top panel) and Heparin II (PDB: 1NFH; bottom panel) binding domains of FN from the corresponding PDB data files. Residues determined as being modified by the MPO-enzyme system are indicated (red = oxidized, purple = chlorinated). The residues involved in fibrin-binding in 109A [67] and heparinbinding in $1 \mathrm{NFH}$ are indicated in yellow [71].

implicate the $\mathrm{N}$-terminal region.

The MPO-specific oxidation site, Trp-65, is located in loop 1 within the fibrin binding site [67] (Fig. 10). This observation is of potential significance, as a previous study has shown that chemical modification of $\operatorname{Trp}$ residues in this domain caused a $90 \%$ loss of heparin binding compared to unmodified controls [68]. Binding of fibrin/fibrinogen plays a key role in thrombus formation important in wound healing and stabilisation of atherosclerotic lesions $[16,69,70]$.

For both the reagent and enzymatic systems, the Hep II domain was heavily modified with two major targets and other lesser sites of modification. The most heavily modified sites (Met-1783, detected as a $+16 \mathrm{~m} / \mathrm{z}$ species; and Tyr-1882, detected as both a mono- and dichlorinated species) are surface exposed in a partial crystal structure of this domain (Fig. 10) [71]. These alterations appear to induce a higher binding affinity of the modified FN towards heparin than the unmodified form, as judged by the increased retention on the heparin column.

Cell adhesion to FN is mediated, at least in part, via interactions with cell-surface integrins, and particularly $\alpha 5 \beta 1$, with the RGD motif present in the cell-binding domain (module III $_{10}$ ) [72]. This interaction appears to be only sufficient for attachment and spreading of the cells, with additional interactions and signalling involving syndecan-4 required for focal adhesion formation, and the arrangement of the actin cytoskeleton into bundled stress fibres $[73,74]$. The signalling induced by these focal adhesions is a prerequisite for gene expression, cell cycle regulation, and control of apoptosis [75]. Syndecan-4 interacts with the Hep II domain of FN through heparin sulfate chains with specific properties [76], and activates protein kinase C- $\alpha$ signalling [77] in the presence of inositol phospholipids (reviewed $[78,79]$ ). Recent data also indicates that the Hep II domain is a binding domain for vascular endothelial cell growth factor (VEGF), and that bound VEGF "talks" to the cell-binding domain, with both domains required for cell adherence, proliferation and migration of endothelial cells and osteoblasts $[80,81]$.

In the current studies, two modifications were detected in the cellbinding domain (Trp-1468, Tyr-1538) with $500 \mu \mathrm{M} \mathrm{HOCl}$. Both residues are distant (within the sequence) from the RGD site (residues
1524-1526), and are modified to only a moderate (Trp-1468) or low extent (Tyr-1538). It is therefore impossible to determine whether these modifications are responsible, possibly via remotely-induced conformational changes, for the decreased HCASMC adherence observed in the current study. However, it is possible that these alterations, in conjunction with those in the Hep II region, may be sufficient to explain the observed decrease in cell adhesion.

The enhanced proliferation and altered gene expression detected for the HCASMC after initial adherence may also arise from the modifications in the Hep II domain, as this domain modulates cell signalling and cell cycle control [75]. The increased expression in PCNA, CCNA 1 and CCNB 1 in HCASMC exposed to HOCl-modified FN is consistent with the enhanced rate of cell growth detected for cells on modified compared to control FN. Modified FN also induced alterations in the expression of genes associated with ECM synthesis and remodelling, with upregulation of some matrix proteins (e.g. LAMA1), a decrease in others (e.g. LAMB2), and upregulation of the expression of multiple MMPs. Increased expression of inflammatory genes, and particularly iNOS and IL-6, were also detected, with higher expression of the latter reflected in increased IL- 6 protein excretion. Together these data suggest that modified FN generates phenotypic changes in adherent HCASMC with these having proliferative and pro-inflammatory characteristics.

These changes are of potential biological significance as it is well established that during the development of atherosclerotic lesions, medial smooth muscle cells switch from a quiescent contractile phenotype to a migratory and proliferative form. The latter migrate into the growing lesion, aided via a disruption of the elastic lamina (arising from either direct oxidation or MMP-mediated), and play an important role in generating the fibrous cap of the lesion via ECM synthesis. The assembly of newly-synthesized ECM by such cells may also be of critical importance, as highly fibrous lesions are less prone to rupture and thrombus formation. In this respect, it is interesting to note that one of the other modifications detected, at Tyr-666 (observed as 3-ClTyr) in the anastellin domain, is critical to superfibronectin formation and fibril assembly [1]. Mutation of this Tyr, together with Leu-663 to Ala, abolishes polymerization activity [82], without affecting FN secondary structure, fibronectin binding, or p38 kinase activation [82,83]. It is therefore possible that the synthesis and assembly of new FN fibres by HCASMC, in the presence of HOCl-modified FN, may be incomplete or modulated as a result of the Tyr-666 chlorination. Altered FN fibre assembly may have downstream consequences, as correct FN fibrillogenesis is a requirement for the correct deposition of other ECM materials including fibrillin-1 microfibrils [84] and collagen-containing structures [85]. The modifications to FN may therefore result in a weakened or modified ECM structure in lesions.

Overall, these data provide novel insights into how damage induced by MPO and its oxidants, can change the ECM environment and have consequent effects on associated cells. Using MS-based quantification of site-specific amino acid modifications we have shown that MPO-generated $\mathrm{HOCl}$ modifies selected regions in $\mathrm{FN}$, with damage observed in functional domains, including damage clusters within the heparinbinding sequence. The modified FN exhibits increased binding affinity for heparin. Human coronary artery smooth muscle cells (HCASMC) show decreased adherence, increased proliferation and growth, and altered gene expression in response to modified FN, with increased expression of genes involved in ECM formation and remodelling. These findings indicate that modified FN may play a major role in the formation, development and stabilisation of fibrous caps in atherosclerotic lesions.

\section{Acknowledgements}

The authors are grateful to the Novo Nordisk Foundation (Grant: NNF13OC0004294) and the Danish Council for Independent Research (Det Frie Forskningsråd, Grant: DFF-7014-00047) for financial support. ARW was supported by Independent Research Fund Denmark - Natural 
Sciences (FNU) and VILLUM Foundation grant to the VILLUM Center for Bioanalytical Sciences at SDU.

\section{Appendix A. Supplementary material}

Supplementary data associated with this article can be found in the online version at doi:10.1016/j.redox.2018.09.005.

\section{References}

[1] P. Singh, C. Carraher, J.E. Schwarzbauer, Assembly of fibronectin extracellular matrix, Annu. Rev. Cell Dev. Biol. 26 (2010) 397-419.

[2] R. Hynes, Molecular biology of fibronectin, Annu. Rev. Cell Biol. 1 (1985) 67-90.

[3] R. Pankov, K.M. Yamada, Fibronectin at a glance, J. Cell Sci. 115 (2002) 3861-3863.

[4] K.S. Midwood, L.V. Williams, J.E. Schwarzbauer, Tissue repair and the dynamics of the extracellular matrix, Int. J. Biochem. Cell Biol. 36 (2004) 1031-1037.

[5] W.S. To, K.S. Midwood, Plasma and cellular fibronectin: distinct and independent functions during tissue repair, Fibrogenes. Tissue Repair 4 (2011) 21.

[6] E.S. White, A.F. Muro, Fibronectin splice variants: understanding their multiple roles in health and disease using engineered mouse models, IUBMB Life 63 (2011) 538-546.

[7] S. Stenman, A. Vaheri, Distribution of a major connective tissue protein, fibronectin, in normal human tissues, J. Exp. Med. 147 (1978) 1054-1064.

[8] M.K. Magnusson, D.F. Mosher, Fibronectin: structure, assembly, and cardiovascular implications, Arterioscler. Thromb. Vasc. Biol. 18 (1998) 1363-1370.

[9] S. Stenman, K. Vonsmitten, A. Vaheri, Fibronectin and atherosclerosis, Acta Med. Scand. (1980) 165-170.

[10] K.S. Song, H.K. Kim, W. Shim, S.H. Jee, Plasma fibronectin levels in ischemic heart disease, Atherosclerosis 154 (2001) 449-453.

[11] M.J. Davies, A.C. Thomas, Plaque fissuring - the cause of acute myocardial infarction, sudden ischaemic death and crescendo angina, Br. Heart J. 53 (1985) 363-373.

[12] A. Fortuno, G. San Jose, M.U. Moreno, J. Diez, G. Zalba, Oxidative stress and vascular remodelling, Exp. Physiol. 90 (2005) 457-462.

[13] A.J. Lusis, Atherosclerosis, Nature 407 (2000) 233-241.

[14] E. Falk, P.K. Shah, V. Fuster, Coronary plaque disruption, Circulation 92 (1995) 657-671.

[15] A.C. van der Wal, A.E. Becker, C.M. van der Loos, P.K. Das, Site of intimal rupture or erosion of thrombosed coronary atherosclerotic plaques is characterized by an inflammatory process irrespective of the dominant plaque morphology, Circulation 89 (1994) 36-44.

[16] I. Rohwedder, E. Montanez, K. Beckmann, E. Bengtsson, P. Duner, J. Nilsson, O. Soehnlein, R. Fassler, Plasma fibronectin deficiency impedes atherosclerosis progression and fibrous cap formation, EMBO Mol. Med. 4 (2012) 564-576.

[17] M.D. Rees, E.C. Kennett, J.M. Whitelock, M.J. Davies, Oxidative damage to extracellular matrix and its role in human pathologies, Free Radic. Biol. Med. 44 (2008) 1973-2001.

[18] C.Y. Chuang, G. Degendorfer, A. Hammer, J.M. Whitelock, E. Malle, M.J. Davies, Oxidation modifies the structure and function of the extracellular matrix generated by human coronary artery endothelial cells, Biochem J. 459 (2014) 313-322.

[19] B. Halliwell, J.M.C. Gutteridge, Free Radicals In Biology \& Medicine, Oxford University Press, Oxford, 2015.

[20] C.C. Winterbourn, A.J. Kettle, M.B. Hampton, Reactive oxygen species and neutrophil function, Annu. Rev. Biochem. 85 (2016) 765-792.

[21] M.J. Davies, C.L. Hawkins, D.I. Pattison, M.D. Rees, Mammalian heme peroxidases: from molecular mechanisms to health implications, Antioxid. Redox Signal. 10 (2008) 1199-1234.

[22] D.I. Pattison, M.J. Davies, Absolute rate constants for the reaction of hypochlorous acid with protein side chains and peptide bonds, Chem. Res. Toxicol. 14 (2001) $1453-1464$

[23] A. Daugherty, J.L. Dunn, D.L. Rateri, J.W. Heinecke, Myeloperoxidase, a catalyst for lipoprotein oxidation, is expressed in human atherosclerotic lesions, J. Clin. Investig. 94 (1994) 437-444.

[24] S.J. Nicholls, S.L. Hazen, Myeloperoxidase and cardiovascular disease, Arterioscler. Thromb. Vasc. Biol. 25 (2005) 1102-1111.

[25] W.H. Tang, Y. Wu, S.J. Nicholls, S.L. Hazen, Plasma myeloperoxidase predicts incident cardiovascular risks in stable patients undergoing medical management for coronary artery disease, Clin. Chem. 57 (2011) 33-39.

[26] M.C. Vissers, C.C. Winterbourn, J.S. Hunt, Degradation of glomerular basement membrane by human neutrophils in vitro, Biochim. Biophys. Acta 804 (1984) 154-160.

[27] M.C.M. Vissers, C.C. Winterbourn, Oxidative damage to fibronectin. 1. The effects of the neutrophil myeloperoxidase system and hocl, Arch. Biochem. Biophys. 285 (1991) 53-59.

[28] M.C.M. Vissers, C. Thomas, Hypochlorous acid disrupts the adhesive properties of subendothelial matrix, Free Radic. Biol. Med. 23 (1997) 401-411.

[29] S. Baldus, J.P. Eiserich, M.L. Brennan, R.M. Jackson, C.B. Alexander, B.A. Freeman, Spatial mapping of pulmonary and vascular nitrotyrosine reveals the pivotal role of myeloperoxidase as a catalyst for tyrosine nitration in inflammatory diseases, Free Radic. Biol. Med. 33 (2002) 1010-1019.

[30] C. Storkey, M.J. Davies, D.I. Pattison, Reevaluation of the rate constants for the reaction of hypochlorous acid (hocl) with cysteine, methionine, and peptide derivatives using a new competition kinetic approach, Free Radic. Biol. Med. 73 (2014) 60-66.

[31] M. Karimi, M.T. Ignasiak, B. Chan, A.K. Croft, L. Radom, C.H. Schiesser, D.I. Pattison, M.J. Davies, Reactivity of disulfide bonds is markedly affected by structure and environment: implications for protein modification and stability, Sci. Rep. 6 (2016) 38572.

[32] C.L. Hawkins, M.J. Davies, Hypochlorite-induced damage to proteins: formation of nitrogen-centred radicals from lysine residues and their role in protein fragmentation, Biochem. J. 332 (1998) 617-625.

[33] C.L. Hawkins, M.J. Davies, Hypochlorite-induced oxidation of proteins in plasma: formation of chloramines and nitrogen-centred radicals and their role in protein fragmentation, Biochem. J. 340 (1999) 539-548.

[34] A.J. Kettle, Neutrophils convert tyrosyl residues in albumin to chlorotyrosine, FEBS Lett. 379 (1996) 103-106.

[35] A.J. Kettle, A.M. Albrett, A.L. Chapman, N. Dickerhof, L.V. Forbes, I. Khalilova, R. Turner, Measuring chlorine bleach in biology and medicine, Biochim. Biophys. Acta 1840 (2014) 781-793.

[36] S.L. Hazen, J.W. Heinecke, 3-chlorotyrosine, a specific marker of myeloperoxidasecatalysed oxidation, is markedly elevated in low density lipoprotein isolated from human atherosclerotic intima, J. Clin. Investig. 99 (1997) 2075-2081.

[37] B. Shao, C. Bergt, X. Fu, P. Green, J.C. Voss, M.N. Oda, J.F. Oram, J.W. Heinecke, Tyrosine 192 in apolipoprotein a-i is the major site of nitration and chlorination by myeloperoxidase, but only chlorination markedly impairs abca1-dependent cholesterol transport, J. Biol. Chem. 280 (2005) 5983-5993.

[38] B. Shao, S. Pennathur, J.W. Heinecke, Myeloperoxidase targets apolipoprotein a-i, the major high density lipoprotein protein, for site-specific oxidation in human atherosclerotic lesions, J. Biol. Chem. 287 (2012) 6375-6386.

[39] L. Zheng, B. Nukuna, M.L. Brennan, M. Sun, M. Goormastic, M. Settle, D. Schmitt, X. Fu, L. Thomson, P.L. Fox, H. Ischiropoulos, J.D. Smith, M. Kinter, S.L. Hazen, Apolipoprotein a-i is a selective target for myeloperoxidase-catalyzed oxidation and functional impairment in subjects with cardiovascular disease, J. Clin. Investig. 114 (2004) 529-541.

[40] A. Undurti, Y. Huang, J.A. Lupica, J.D. Smith, J.A. DiDonato, S.L. Hazen, Modification of high density lipoprotein by myeloperoxidase generates a pro-inflammatory particle, J. Biol. Chem. 284 (2009) 30825-30835.

[41] T. Nybo, M.J. Davies, A. Rogowska-Wrzesinska, Analysis of protein chlorination by mass spectrometry, Redox Biol. (2018) (submitted for publication).

[42] J.M. Dypbukt, C. Bishop, W.M. Brooks, B. Thong, H. Eriksson, A.J. Kettle, A sensitive and selective assay for chloramine production by myeloperoxidase, Free Radic. Biol. Med. 39 (2005) 1468-1477.

[43] A.J. Kettle, C.C. Winterbourn, Assays for the chlorination activity of myeloperoxidase, Methods Enzymol. 233 (1994) 502-512.

[44] T. Masuda, M. Tomita, Y. Ishihama, Phase transfer surfactant-aided trypsin digestion for membrane proteome analysis, J. Proteome Res. 7 (2008) 731-740.

[45] R.E. Ferguson, H.P. Carroll, A. Harris, E.R. Maher, P.J. Selby, R.E. Banks, Housekeeping proteins: a preliminary study illustrating some limitations as useful references in protein expression studies, Proteomics 5 (2005) 566-571.

[46] K. Tveen-Jensen, A. Reis, L. Mouls, A.R. Pitt, C.M. Spickett, Reporter ion-based mass spectrometry approaches for the detection of non-enzymatic protein modifications in biological samples, J. Proteom. 92 (2013) 71-79.

[47] J. Talib, D.I. Pattison, J.A. Harmer, D.S. Celermajer, M.J. Davies, High plasma thiocyanate levels modulate protein damage induced by myeloperoxidase and perturb measurement of 3-chlorotyrosine, Free Radic. Biol. Med. 53 (2012) 20-29.

[48] H.J. Chen, Y.F. Yang, P.Y. Lai, P.F. Chen, Analysis of chlorination, nitration, and nitrosylation of tyrosine and oxidation of methionine and cysteine in hemoglobin from type 2 diabetes mellitus patients by nanoflow liquid chromatography tandem mass spectrometry, Anal. Chem. 88 (2016) 9276-9284.

[49] E.C. Kennett, M.D. Rees, E. Malle, A. Hammer, J.M. Whitelock, M.J. Davies, Peroxynitrite modifies the structure and function of the extracellular matrix proteoglycan perlecan by reaction with both the protein core and the heparan sulfate chains, Free Radic. Biol. Med 49 (2010) 282-293.

[50] M.D. Rees, J.M. Whitelock, E. Malle, C.Y. Chuang, R.V. Iozzo, A. Nilasaroya, M.J. Davies, Myeloperoxidase-derived oxidants selectively disrupt the protein core of the heparan sulfate proteoglycan perlecan, Matrix Biol. 29 (2010) 63-73.

[51] G. Degendorfer, C.Y. Chuang, A. Hammer, E. Malle, M.J. Davies, Peroxynitrous acid induces structural and functional modifications to basement membranes and its key component, laminin, Free Radic. Biol. Med. 89 (2015) 721-733.

[52] G. Degendorfer, C.Y. Chuang, M. Mariotti, A. Hammer, G. Hoefler, P. Hagglund, E. Malle, S.G. Wise, M.J. Davies, Exposure of tropoelastin to peroxynitrous acid gives high yields of nitrated tyrosine residues, di-tyrosine cross-links and altered protein structure and function, Free Radic. Biol. Med. 115 (2017) 219-231.

[53] G. Degendorfer, C.Y. Chuang, H. Kawasaki, A. Hammer, E. Malle, F. Yamakura, M.J. Davies, Peroxynitrite-mediated oxidation of plasma fibronectin, Free Radic. Biol. Med. 97 (2016) 602-615.

[54] C. Leeuwenburgh, M.M. Hardy, S.L. Hazen, P. Wagner, S. Oh-ishi, U.P. Steinbrecher, J.W. Heinecke, Reactive nitrogen intermediates promote low density lipoprotein oxidation in human atherosclerotic intima, J. Biol. Chem. 272 (1997) 1433-1436.

[55] G. Ferrer-Sueta, N. Campolo, M. Trujillo, S. Bartesaghi, S. Carballal, N. Romero, B. Alvarez, R. Radi, Biochemistry of peroxynitrite and protein tyrosine nitration, Chem. Rev. 118 (2018) 1338-1408.

[56] M.D. Rees, L. Dang, T. Thai, D.M. Owen, E. Malle, S.R. Thomas, Targeted subendothelial matrix oxidation by myeloperoxidase triggers myosin ii-dependent deadhesion and alters signaling in endothelial cells, Free Radic. Biol. Med. 53 (2012) 2344-2356.

[57] S. Vanichkitrungruang, C.Y. Chuang, M.J. Davies, Oxidation of human plasma 
fibronectin by hypochlorous (HOCL) and hypothiocyanous (HOSCN) acids perturbs endothelial cell function, Free Radic. Biol. Med. (2018) (submitted for publication).

[58] M.L. Brennan, M.S. Penn, F. Van Lente, V. Nambi, M.H. Shishehbor, R.J. Aviles, M. Goormastic, M.L. Pepoy, E.S. McErlean, E.J. Topol, S.E. Nissen, S.L. Hazen, Prognostic value of myeloperoxidase in patients with chest pain, N. Engl. J. Med. 349 (2003) 1595-1604.

[59] W.H.W. Tang, M.L. Brennan, K. Philip, W. Tong, S. Mann, F. Van Lente, S.L. Hazen, Plasma myeloperoxidase levels in patients with chronic heart failure, Am. J. Cardiol. 98 (2006) 796-799.

[60] R. Zhang, M.L. Brennan, X. Fu, R.J. Aviles, G.L. Pearce, M.S. Penn, E.J. Topol, D.L. Sprecher, S.L. Hazen, Association between myeloperoxidase levels and risk of coronary artery disease, JAMA 286 (2001) 2136-2142.

[61] S.J. Nicholls, W.H. Wilson Tang, D. Brennan, M.L. Brennan, S. Mann, S.E. Nissen, S.L. Hazen, Risk prediction with serial myeloperoxidase monitoring in patients with acute chest pain, Clin. Chem. 57 (2011) 1762-1770.

[62] S. Baldus, C. Heeschen, T. Meinertz, A.M. Zeiher, J.P. Eiserich, T. Munzel, M.L. Simoons, C.W. Hamm, Myeloperoxidase serum levels predict risk in patients with acute coronary syndromes, Circulation 108 (2003) 1440-1445.

[63] V. Rudolph, B.U. Goldmann, C. Bos, T.K. Rudolph, A. Klinke, K. Friedrichs, D. Lau, K. Wegscheider, M. Haddad, T. Meinertz, S. Baldus, Diagnostic value of mpo plasma levels in patients admitted for suspected myocardial infarction, Int. J. Cardiol. 153 (2010) 267-271.

[64] D.I. Pattison, M.J. Davies, C.L. Hawkins, Reactions and reactivity of myeloperoxidase-derived oxidants: differential biological effects of hypochlorous and hypothiocyanous acids, Free Radic. Res. 46 (2012) 975-995.

[65] L. Kubala, H. Kolarova, J. Vitecek, S. Kremserova, A. Klinke, D. Lau, A.L. Chapman, S. Baldus, J.P. Eiserich, The potentiation of myeloperoxidase activity by the glycosaminoglycan-dependent binding of myeloperoxidase to proteins of the extracellular matrix, Biochim. Biophys. Acta 2013 (1830) 4524-4536.

[66] S. Baldus, J.P. Eiserich, A. Mani, L. Castro, M. Figueroa, P. Chumley, W. Ma, A. Tousson, T.C.R. White, D.C. Bullard, M.-L. Brennan, A.J. Lusis, K.P. Moore, B.A. Freeman, Endothelial transcytosis of myeloperoxidase confers specificity to vascular ecm proteins as targets of tyrosine nitration, J. Clin. Investig. 108 (2001) 1759-1770.

[67] U. Schwarz-Linek, J.M. Werner, A.R. Pickford, S. Gurusiddappa, J.H. Kim, E.S. Pilka, J.A. Briggs, T.S. Gough, M. Hook, I.D. Campbell, J.R. Potts, Pathogenic bacteria attach to human fibronectin through a tandem beta-zipper, Nature 423 (2003) 177-181.

[68] G.A. Homandberg, J. Kramer-Bjerke, D. Grant, G. Christianson, R. Eisenstein, Heparin-binding fragments of fibronectin are potent inhibitors of endothelial cell growth: structure-function correlations, Biochim. Biophys. Acta 874 (1986) 61-71.

[69] E. Makogonenko, G. Tsurupa, K. Ingham, L. Medved, Interaction of fibrin(ogen) with fibronectin: further characterization and localization of the fibronectinbinding site, Biochemistry 41 (2002) 7907-7913.

[70] H. Ni, P.S. Yuen, J.M. Papalia, J.E. Trevithick, T. Sakai, R. Fassler, R.O. Hynes, D.D. Wagner, Plasma fibronectin promotes thrombus growth and stability in injured arterioles, Proc. Natl. Acad. Sci. USA 100 (2003) 2415-2419.
[71] A. Sharma, J.A. Askari, M.J. Humphries, E.Y. Jones, D.I. Stuart, Crystal structure of a heparin- and integrin-binding segment of human fibronectin, EMBO J. 18 (1999) 1468-1479.

[72] R. Pytela, M.D. Pierschbacher, E. Ruoslahti, Identification and isolation of a $140 \mathrm{kd}$ cell surface glycoprotein with properties expected of a fibronectin receptor, Cell 40 (1985) 191-198.

[73] A. Woods, J.R. Couchman, S. Johansson, M. Hook, Adhesion and cytoskeletal organisation of fibroblasts in response to fibronectin fragments, EMBO J. 5 (1986) $665-670$

[74] L. Bloom, K.C. Ingham, R.O. Hynes, Fibronectin regulates assembly of actin filaments and focal contacts in cultured cells via the heparin-binding site in repeat iii13, Mol. Biol. Cell 10 (1999) 1521-1536.

[75] A. Woods, J.R. Couchman, Syndecan-4 and focal adhesion function, Curr. Opin. Cell Biol. 13 (2001) 578-583.

[76] Y. Mahalingam, J.T. Gallagher, J.R. Couchman, Cellular adhesion responses to the heparin-binding (hepii) domain of fibronectin require heparan sulfate with specific properties, J. Biol. Chem. 282 (2007) 3221-3230.

[77] S.T. Lim, R.L. Longley, J.R. Couchman, A. Woods, Direct binding of syndecan-4 cytoplasmic domain to the catalytic domain of protein kinase c alpha (pkc alpha) increases focal adhesion localization of pkc alpha, J. Biol. Chem. 278 (2003) 13795-13802.

[78] J.R. Couchman, Syndecans: proteoglycan regulators of cell-surface microdomains? Nat. Rev. Mol. Cell Biol. 4 (2003) 926-937.

[79] M.D. Bass, M.J. Humphries, Cytoplasmic interactions of syndecan-4 orchestrate adhesion receptor and growth factor receptor signalling, Biochem. J. 368 (2002) $1-15$.

[80] E.S. Wijelath, S. Rahman, M. Namekata, J. Murray, T. Nishimura, Z. MostafaviPour, Y. Patel, Y. Suda, M.J. Humphries, M. Sobel, Heparin-ii domain of fibronectin is a vascular endothelial growth factor-binding domain: enhancement of vegf biological activity by a singular growth factor/matrix protein synergism, Circ. Res. 99 (2006) 853-860.

[81] J.H. Kim, S.O. Park, H.J. Jang, J.H. Jang, Importance of the heparin-binding domain of fibronectin for enhancing cell adhesion activity of the recombinant fibronectin, Biotechnol. Lett. 28 (2006) 1409-1413.

[82] K. Briknarova, M.E. Akerman, D.W. Hoyt, E. Ruoslahti, K.R. Ely, Anastellin, an fn3 fragment with fibronectin polymerization activity, resembles amyloid fibril precursors, J. Mol. Biol. 332 (2003) 205-215.

[83] R. You, R.M. Klein, M. Zheng, P.J. McKeown-Longo, Regulation of p38 map kinase by anastellin is independent of anastellin's effect on matrix fibronectin, Matrix Biol. 28 (2009) 101-109.

[84] R. Kinsey, M.R. Williamson, S. Chaudhry, K.T. Mellody, A. McGovern, S. Takahashi, C.A. Shuttleworth, C.M. Kielty, Fibrillin-1 microfibril deposition is dependent on fibronectin assembly, J. Cell Sci. 121 (2008) 2696-2704.

[85] J.A. McDonald, D.G. Kelley, T.J. Broekelmann, Role of fibronectin in collagen deposition: fab' to the gelatin-binding domain of fibronectin inhibits both fibronectin and collagen organization in fibroblast extracellular matrix, J. Cell Biol. 92 (1982) 485-492. 